
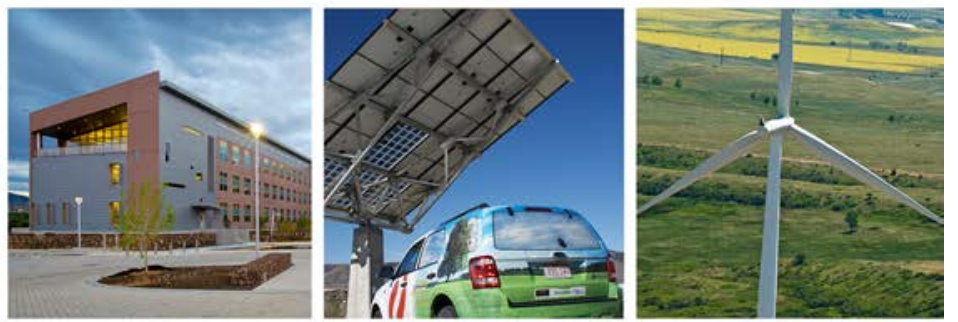

\title{
BC Transit Fuel Cell Bus Project: Evaluation Results Report
}

L. Eudy and M. Post National Renewable Energy Laboratory

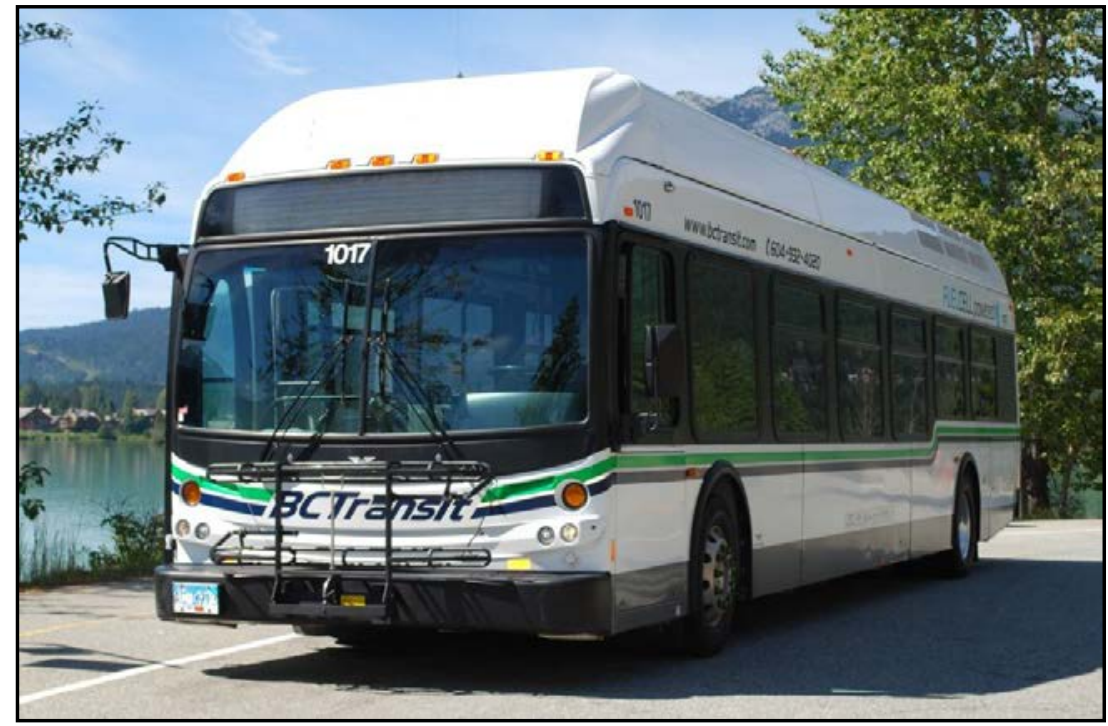

NREL is a national laboratory of the U.S. Department of Energy Office of Energy Efficiency \& Renewable Energy Operated by the Alliance for Sustainable Energy, LLC

This report is available at no cost from the National Renewable Energy Laboratory (NREL) at www.nrel.gov/publications.

Technical Report

NREL/TP-5400-60603

February 2014

Contract No. DE-AC36-08G028308 


\title{
BC Transit Fuel Cell Bus Project: Evaluation Results Report
}

\author{
L. Eudy and M. Post \\ National Renewable Energy Laboratory
}

Prepared under Task No. WW4K.1000

NREL is a national laboratory of the U.S. Department of Energy Office of Energy Efficiency \& Renewable Energy Operated by the Alliance for Sustainable Energy, LLC

This report is available at no cost from the National Renewable Energy Laboratory (NREL) at www.nrel.gov/publications.

National Renewable Energy Laboratory 15013 Denver West Parkway Golden, CO 80401

303-275-3000 • www.nrel.gov

\section{Technical Report}

NREL/TP-5400-60603

February 2014

Contract No. DE-AC36-08G028308 


\section{NOTICE}

This report was prepared as an account of work sponsored by an agency of the United States government. Neither the United States government nor any agency thereof, nor any of their employees, makes any warranty, express or implied, or assumes any legal liability or responsibility for the accuracy, completeness, or usefulness of any information, apparatus, product, or process disclosed, or represents that its use would not infringe privately owned rights. Reference herein to any specific commercial product, process, or service by trade name, trademark, manufacturer, or otherwise does not necessarily constitute or imply its endorsement, recommendation, or favoring by the United States government or any agency thereof. The views and opinions of authors expressed herein do not necessarily state or reflect those of the United States government or any agency thereof.

This report is available at no cost from the National Renewable Energy Laboratory (NREL) at www.nrel.gov/publications.

Available electronically at http://www.osti.gov/scitech

Available for a processing fee to U.S. Department of Energy and its contractors, in paper, from:

U.S. Department of Energy

Office of Scientific and Technical Information

P.O. Box 62

Oak Ridge, TN 37831-0062

phone: 865.576 .8401

fax: 865.576 .5728

email: mailto:reports@adonis.osti.gov

Available for sale to the public, in paper, from:

U.S. Department of Commerce

National Technical Information Service

5285 Port Royal Road

Springfield, VA 22161

phone: 800.553 .6847

fax: 703.605.6900

email: orders@ntis.fedworld.gov

online ordering: http://www.ntis.gov/help/ordermethods.aspx

Cover Photos: (left to right) photo by Pat Corkery, NREL 16416, photo from SunEdison, NREL 17423, photo by Pat Corkery, NREL 16560, photo by Dennis Schroeder, NREL 17613, photo by Dean Armstrong, NREL 17436, photo by Pat Corkery, NREL 17721. 


\section{Acknowledgments}

This evaluation at BC Transit would not have been possible without the support and cooperation of many people. The authors thank the following individuals:

California Air Resources Board

Lesley Stern

Gerhard Achtelik

DOE's National Renewable Energy Laboratory

Sam Sprik

BC Transit

Mike Frost

Aaron Lamb

Steve Brydon

Todd Thompson

Whistler Transit

Juan Carlos Gomez

Todd Peterson

Ballard Power Systems

Byron Somerville

Jeff Grant

New Flyer

Chris Stoddart

Air Liquide

Bruno Forget

Reid Rothwell \& Associates

Bruce Rothwell

Unless otherwise noted, all photos by L. Eudy, NREL 


\section{Acronyms and Abbreviations}

\begin{tabular}{ll} 
CARB & California Air Resources Board \\
CAD & Canadian dollar \\
DGE & diesel gallon equivalent \\
DOE & U.S. Department of Energy \\
FCEB & fuel cell electric bus \\
FCPP & fuel cell power plant \\
ft & feet \\
FTA & Federal Transit Administration \\
GVWR & gross vehicle weight rating \\
hp & horsepower \\
HVAC & heating, ventilation, and air conditioning \\
in. & inches \\
kg & kilograms \\
kW & kilowatts \\
kWh & kilowatt hour \\
lb & pounds \\
MBRC & miles between roadcalls \\
mi/DGE & miles per diesel gallon equivalent \\
mpg & miles per gallon \\
mph & miles per hour \\
NFCBP & National Fuel Cell Bus Program \\
NREL & National Renewable Energy Laboratory \\
PMI & preventive maintenance inspection \\
psi & pounds per square inch \\
RC & roadcall \\
SI & International System of Units \\
USD & U.S. dollar \\
ZEBA & Zero Emission Bay Area \\
& \\
\hline &
\end{tabular}




\section{Definition of Terms}

Availability: The percentage of days the buses are actually available compared to the days that the buses are planned for operation.

Balance of plant: The components of the fuel cell system — such as air compressor, fans, and pumps - that support the operation of the fuel cell stack.

Fast-fill: Completion of a full fill of a hydrogen-fueled bus in 10 minutes or less.

Miles between roadcall (MBRC): A measure of reliability calculated by dividing the number of miles traveled by the number of roadcalls. MBRC in the report are categorized as follows:

- $\quad$ MBRC - bus: Includes all chargeable roadcalls. Includes propulsion-related issues as well as problems with bus-related systems such as brakes, suspension, steering, windows, doors, and tires.

- $\mathrm{MBRC}$ - propulsion-related: Includes roadcalls that are attributed to the propulsion system. Propulsion-related roadcalls can be caused by issues with the power system (fuel cell), batteries, and hybrid systems.

- $\quad \mathrm{MBRC}$ - fuel-cell-related: Includes roadcalls attributed to the fuel cell power plant and balance of plant only.

Revenue service: The time when a vehicle is available to the general public with an expectation of carrying fare-paying passengers. Vehicles operated in a fare-free service are also considered revenue service.

Roadcall: A failure of an in-service bus that causes the bus to be replaced on route or causes a significant delay in schedule. The analysis includes chargeable roadcalls that affect the operation of the bus or may cause a safety hazard. Non-chargeable roadcalls can be passenger incidents that require the bus to be cleaned before going back into service, or problems with an accessory such as a farebox or radio. 


\section{Executive Summary}

British Columbia Transit (BC Transit) has been leading a demonstration of fuel cell electric buses (FCEB) in Whistler, Canada, since early 2010. This 20-bus demonstration was introduced during the 2010 Winter Olympic Games and is the world's largest FCEB fleet in a single location. The demonstration in Whistler is a true test for the technology because the FCEBs form the backbone of the fleet -20 out of 23 buses (plus three additional buses required during peak season to meet mid-day fueling needs). The Whistler resort area has a particularly challenging duty cycle for buses with wide temperature differences between the seasons, steep grades, and heavy passenger loads during peak season.

BC Transit is collaborating with the California Air Resources Board (CARB) and the U.S. Department of Energy's (DOE) National Renewable Energy Laboratory (NREL) to evaluate the buses in revenue service. CARB has enlisted NREL to conduct a third-party evaluation of the BC Transit fleet to aid in understanding the status of the technology in transit. CARB staff has been gathering data on zero-emission buses to assess the status of the technologies as directed by the Board during the July 2009 hearing. While the BC Transit fleet is located outside of the United States, the operation of transit fleets within Canada is similar to that of fleets in the United States. The bus is designed for the North American market, and future models could be built to meet 'Buy America' requirements for U.S. transit agencies. This report covers two years of revenue service data on the buses from April 2011 through March 2013.

The FCEBs are 42-foot, low-floor buses built by New Flyer with a hybrid electric propulsion system that includes a Ballard Power Systems fuel cell and lithium phosphate batteries. The primary goal of the project was to integrate hydrogen fuel cell buses into the regular service of an urban transit system and to monitor the fleet's operations, maintenance, and fueling over a sustained period.

Fueling a 20-bus FCEB fleet requires a station capable of dispensing a significant amount of hydrogen - up to $800 \mathrm{~kg}$ per day when the entire fleet is operating. The hydrogen station at Whistler is a liquid hydrogen storage and gaseous dispensing station and is designed to fast-fill (10 minutes or less) up to 20 buses per day.

In 2012, NREL developed a guideline for evaluating the technology readiness level (TRL) for FCEBs. TRLs go from concept design at TRL 1 up to full commercialization and deployment at TRL 9. Using this guide, the BC Transit buses are considered to be at TRL 7: full-scale validation in a relevant environment. Table ES-1 provides a summary of the data included in this evaluation report in international (SI) and U.S. units. During the two-year data period analyzed for the report, the FCEB fleet has accumulated more than 2.1 million kilometers and more than 156,000 hours on the fuel cell power plants. ${ }^{1}$ Overall the FCEBs have an average fuel consumption of 15.48 kilograms of hydrogen per 100 kilometers. This equates to a fuel economy of 4.53 miles per diesel gallon equivalent (mi/DGE). The buses have an average availability of $69 \%$.

\footnotetext{
${ }^{1}$ Hours data include time accumulated on a total of 22 fuel cell power plants; two are used as spares.
} 
Table ES-1. Summary of Evaluation Results

\begin{tabular}{|l|c|c|}
\hline \multicolumn{1}{|c|}{ Data Item } & SI units & U.S. units \\
\hline Number of buses & 20 & 20 \\
\hline Data period & $4 / 11-3 / 13$ & $4 / 11-3 / 13$ \\
\hline Number of months & 24 & 24 \\
\hline Total distance traveled in period & $2,122,451 \mathrm{~km}$ & $1,318,830 \mathrm{mi}$ \\
\hline Average monthly distance per bus & $4,422 \mathrm{~km}$ & $2,748 \mathrm{mi}$ \\
\hline Total fuel cell operating hours & 156,887 & 156,887 \\
\hline Availability (85\% is target) & 69 & 69 \\
\hline Fuel consumption/fuel economy & $15.48 \mathrm{~kg} / 100 \mathrm{~km}$ & $4.01 \mathrm{mi} / \mathrm{kg}$ \\
\hline $\begin{array}{l}\text { Diesel equivalent fuel consumption/fuel } \\
\text { economy }\end{array}$ & $51.86 \mathrm{~L} / 100 \mathrm{~km}$ & $4.53 \mathrm{mi} / \mathrm{DGE}$ \\
\hline Distance between roadcalls ${ }^{2}$-bus & $2,451 \mathrm{~km}$ & $1,523 \mathrm{mi}$ \\
\hline $\begin{array}{l}\text { Distance between roadcalls-propulsion- } \\
\text { related }\end{array}$ & $3,240 \mathrm{~km}$ & $2,013 \mathrm{mi}$ \\
\hline $\begin{array}{l}\text { Distance between roadcalls-fuel-cell- } \\
\text { related }\end{array}$ & $13,433 \mathrm{~km}$ & $8,347 \mathrm{mi}$ \\
\hline Total maintenance & $\$ 1.03 \mathrm{CAD}$ & $\$ 1.60 \mathrm{USD}$ \\
\hline Maintenance-propulsion only & $\$ 0.59 \mathrm{CAD}$ & $\$ 0.91 \mathrm{USD}$ \\
\hline
\end{tabular}

From BC Transit's perspective, there have been many achievements for the demonstration, including the following:

- The project was delivered on-time and on-budget.

- The FCEBs have accumulated more than 3 million kilometers in revenue service, operating up to 22 hours a day in a wide range of temperatures.

- By operating the FCEBs, the agency has avoided more than 4,400 tons of $\mathrm{CO}_{2}$ compared to using diesel.

- The FCEBs have been incorporated into the fleet, fully maintained by Whistler Transit staff.

The challenges and lessons learned so far include bus-related problems and programmatic issues, as well as market developments with manufacturers that affected the availability of parts. Busrelated challenges included issues with the air compressor, motor, and controller for the fuel cell; battery balance issues; and fuel cell balance of plant issues. Overall maintenance costs have been $58 \%$ higher for the FCEBs than for conventional diesel buses. Corrective repairs for the propulsion system account for more than half the cost.

BC Transit will continue to operate the FCEBs through the end of the planned demonstration period in March 2014. NREL will collect data through the end of this period and plans to publish a second report outlining the final performance results in mid-2014.

\footnotetext{
${ }^{2}$ A roadcall is a failure of an in-service bus that causes the bus to be replaced on route or causes a significant delay in schedule.
} 


\section{Table of Contents}

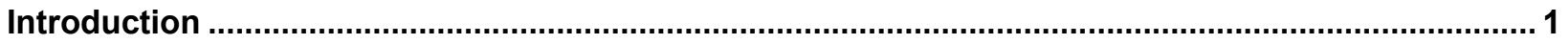

California Fleet Rule for Transit Agencies and Zero-Emission Buses............................................... 1

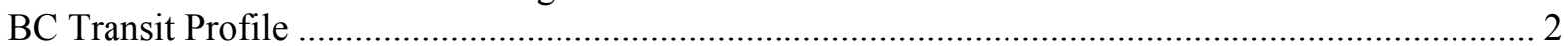

Description of the BC Transit Fuel Cell Bus Program ................................................................... 2

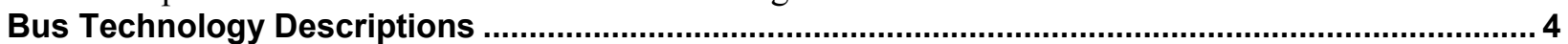

FCEB Development Process_-Technology Readiness Levels....................................................... 5

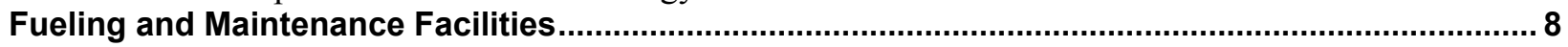

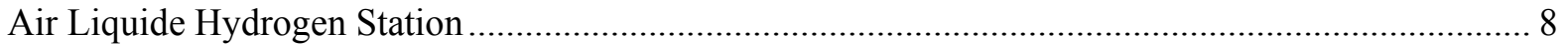

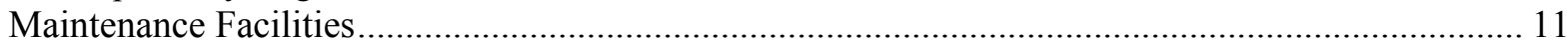

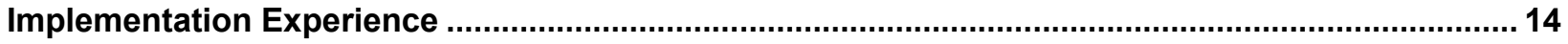

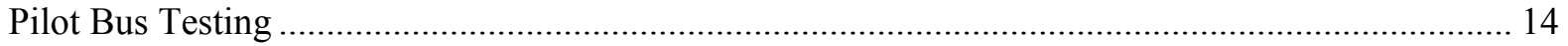

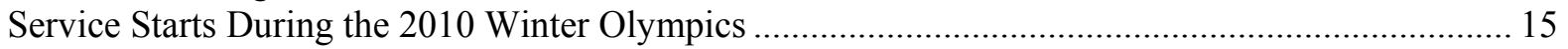

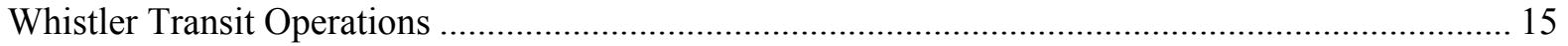

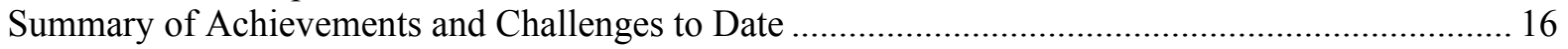

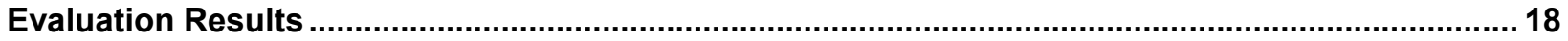

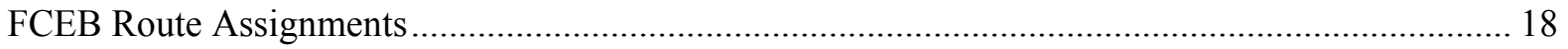

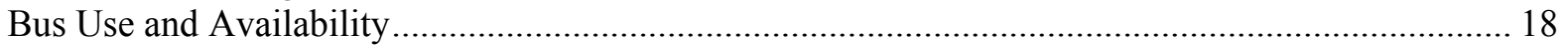

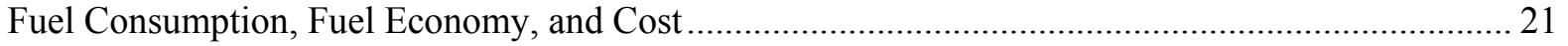

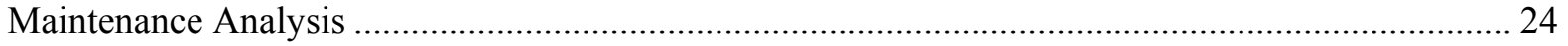

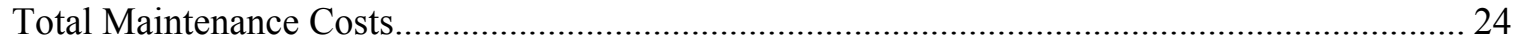

Maintenance Costs Categorized by System ....................................................................... 27

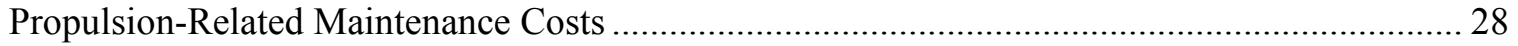

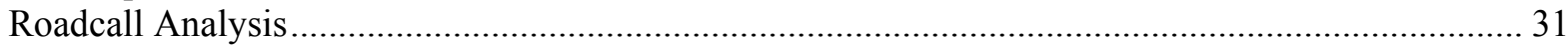

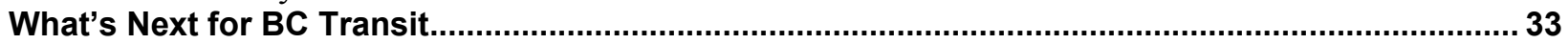

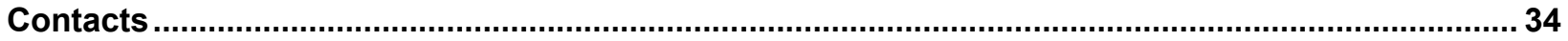

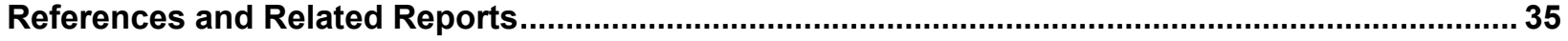

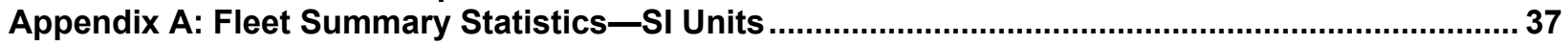

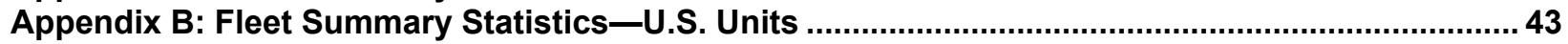




\section{Introduction}

British Columbia Transit (BC Transit) has been leading a demonstration of fuel cell electric buses (FCEB) in Whistler, Canada, since early 2010. This 20-bus demonstration fleet was introduced during the 2010 Winter Olympic Games and is the world's largest FCEB fleet in a single location.

BC Transit is collaborating with the California Air Resources Board (CARB) and the U.S. Department of Energy's (DOE) National Renewable Energy Laboratory (NREL) to evaluate the buses in revenue service. NREL has been evaluating FCEBs under funding from DOE and the U.S. Department of Transportation's Federal Transit Administration (FTA). NREL uses a standard data-collection and analysis protocol originally developed for DOE heavy-duty vehicle evaluations. This protocol was documented in a joint evaluation plan for transit bus evaluations. ${ }^{3}$ The objectives of these evaluations are to provide comprehensive, unbiased evaluation results of fuel cell bus development and performance compared to conventional baseline vehicles.

CARB has enlisted NREL to conduct a third-party evaluation of the BC Transit fleet. CARB staff has been gathering data on zero-emission buses to assess the status of the technologies as directed by the Board during the July 2009 hearing. While the BC Transit fleet is located outside of the United States, the operation of transit fleets within Canada is similar to that of fleets in the United States. The bus is designed for the North American market, and future models could be built to meet 'Buy America' requirements for U.S. transit agencies. This report covers two years of revenue service data on the buses from April 2011 through March 2013. A second report is planned to cover an additional year through the end of the demonstration (March 2014).

\section{California Fleet Rule for Transit Agencies and Zero-Emission Buses}

In 2000, CARB established a new transit bus fleet rule that set more stringent emission standards for new urban bus engines, set fleet emission averages, and promoted advances in the cleanest technologies - specifically, zero-emission buses (ZBuses). All transit agencies with 200 or more urban buses were required to eventually procure ZBuses as $15 \%$ of all new bus purchases. ZBus technologies that qualify for this regulation would be those with zero tailpipe emissions. Current bus technologies that meet this requirement use an electric propulsion system - battery, trolley, or fuel cell.

Several zero-emission bus demonstrations were required as part of the regulation. These demonstrations would begin the introduction of ZBuses and provide data to help determine the status of the technology. Once CARB staff had sufficient data and results on the ZBus demonstrations, they were to prepare a report to the Board with an assessment of the status of the technology and recommendations on how to move forward with the purchase requirements.

All of the early demonstration programs in the state fielded FCEBs. At that time, battery electric buses were smaller vehicles that were plugged in for overnight charging. Transit agencies selected fuel cell technology because the manufacturers could integrate the system on full-size buses and there were fewer issues with limited range than with battery buses. The primary FCEB

\footnotetext{
${ }^{3}$ Fuel Cell Transit Bus Evaluations: Joint Evaluation Plan for the U.S. Department of Energy and the Federal Transit Administration, NREL/MP-560-49342-1, November 2010, www.nrel.gov/hydrogen/pdfs/49342-1.pdf.
} 
demonstration in the state is located at Alameda Contra Costa Transit (AC Transit) and is referred to as the Zero Emission Bay Area (ZEBA) project. The ZEBA project is operating 12 buses and has partners from four Bay Area transit agencies that are subject to the ZBus regulation. This demonstration and smaller demonstration programs in California have taken more time than originally estimated, and delays have resulted in fewer data available for evaluation. In an effort to expand the data set, CARB has provided funding to NREL for the evaluation of the BC Transit fleet. The analysis of BC Transit's ZBus fleet will add performance results of a second large scale demonstration and provide a much broader picture of the status of the technology.

\section{BC Transit Profile}

BC Transit is the provincial Crown agency responsible for coordinating and providing public transportation throughout British Columbia, Canada, with the exception of the metro Vancouver area. Headquartered in Victoria, BC Transit provides service to more than 1.5 million residents in 130 communities around the province. Whistler Transit, funded by the Resort Municipality of Whistler and $\mathrm{BC}$ Transit, provides service to the Whistler/Blackcomb communities of British Columbia. The Whistler resort area has a particularly challenging duty cycle for buses; extreme grades, ${ }^{4}$ seasonal crush loading, cold temperatures, and wet conditions can cause high wear and tear on a transit bus. Figure 1 shows the service area of Whistler Transit. The fleet at Whistler consists of 23 buses: 20 FCEBs and 3 diesel buses. During the winter season, three more conventional buses are added to accommodate mid-day fueling requirements for the FCEBs during the peak season. Whistler Transit operates nine fixed routes, including a commuter service to a local community. The FCEBs are not used on the commuter route.

\section{Description of the BC Transit Fuel Cell Bus Program}

The province of British Columbia is committed to sustainable solutions to reduce greenhouse gas emissions and has a goal of cutting greenhouse gas emissions by $33 \%$ by 2020 . To demonstrate the potential of hydrogen technology as a zero-emission energy solution, the province initiated a demonstration program to deploy a fleet of FCEBs. The BC Transit FCEB program is a fiveyear, $\$ 89$ million project funded by the Canadian federal government, the province of $\mathrm{BC}$, and the Canadian Hydrogen and Fuel Cell Association. The funds cover the incremental cost (over conventional diesel) for the project through March 2014 - both capital and operating costs for the buses and fueling station. The fleet was rolled out in February 2010 during the Winter Olympic Games.

The primary goal of the project is to integrate hydrogen fuel cell buses into the regular service of an urban transit system and to monitor the fleet's operations, maintenance, and fueling over a sustained period.

The demonstration in Whistler is a true test for the technology because the FCEBs form the backbone of the fleet. Other demonstrations have typically consisted of small numbers of FCEBs within much larger conventional fleets; when a demonstration bus is down, the agency has other buses sufficient to meet service requirements. The FCEBs in Whistler make up nearly $90 \%$ of the entire fleet - if too many are out of service, the agency must bring in contingency diesel buses to

\footnotetext{
${ }^{4}$ The maximum ascent grade for the fleet is $16.3 \%$.
} 
meet service requirements. As a result, the agency must be committed to making the technology work.

In addition to the new buses, the project includes the largest hydrogen station in the world, built and operated under contract by Air Liquide. The project also covered the costs for upgrades to handle hydrogen-fueled buses safely in a new maintenance facility.

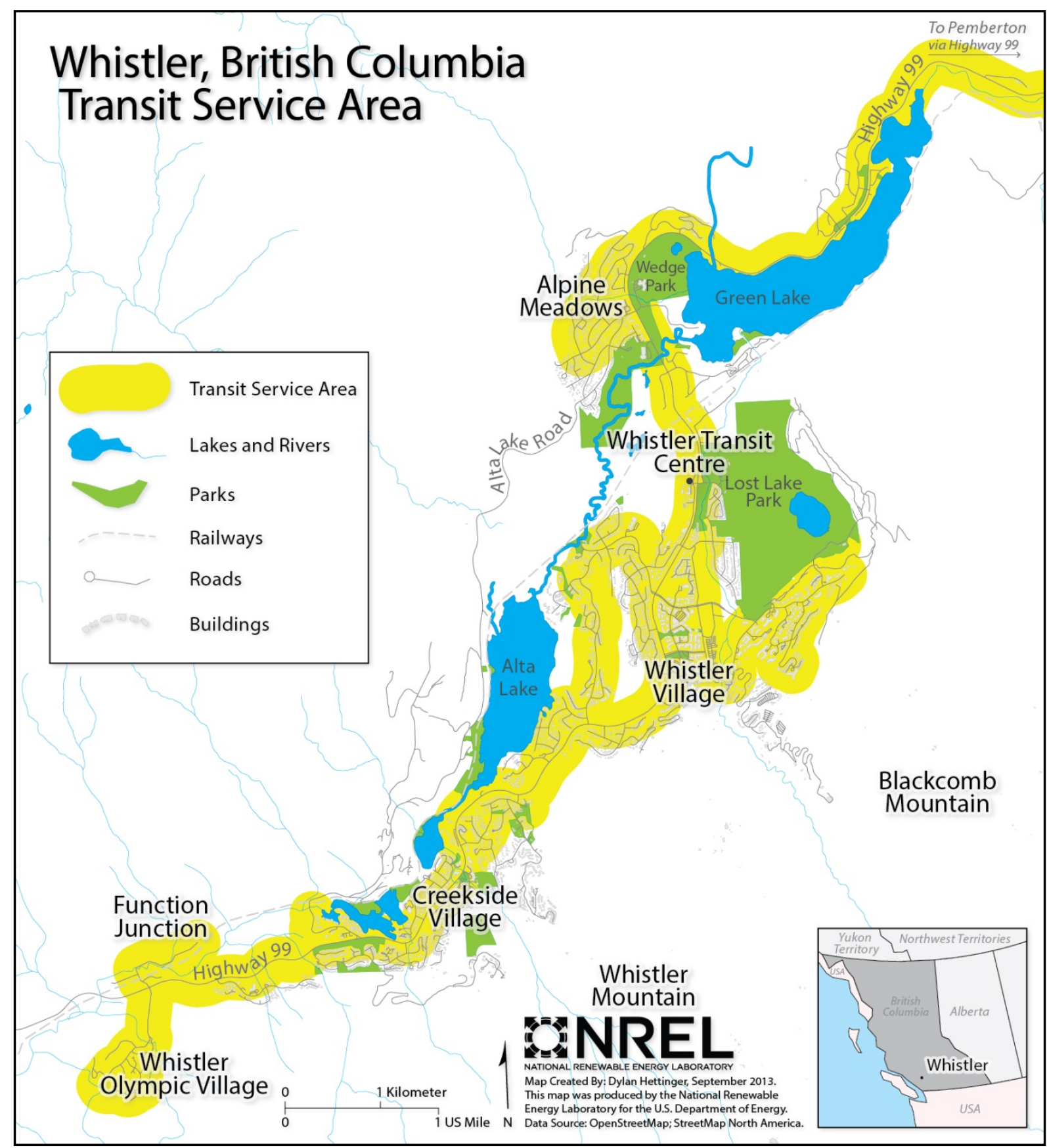

Figure 1. Map of Whistler Transit service area 


\section{Bus Technology Descriptions}

The FCEBs in service primarily at Whistler Transit (Figure 2) are 42-foot, low-floor buses built by New Flyer with a hybrid electric propulsion system that includes a Ballard Power Systems fuel cell. Table 1 provides bus system descriptions for the BC Transit fuel cell buses. Whistler Transit provided data on the FCEBs as well as a selection of diesel buses operated from the same location. Figure 3 shows one of Whistler Transit's diesel buses. The fuel cell and diesel buses are operated on different routes. Those routes and the implications for comparison are discussed later in this report.

Table 1. Fuel Cell Bus System Description

\begin{tabular}{|l|l|}
\hline \multicolumn{1}{|c|}{ Vehicle System } & \multicolumn{1}{c|}{ Fuel Cell } \\
\hline Number of buses & 20 \\
\hline Bus manufacturer and model & New Flyer H40LFR \\
\hline Model year & 2009 \\
\hline Length/width/height & $12.5 \mathrm{~m} / 2.59 \mathrm{~m} / 3.35 \mathrm{~m}(42 \mathrm{ft} / 102 \mathrm{in} . / 132 \mathrm{in})$. \\
\hline GVWR/curb weight & $20,185 \mathrm{~kg} / 15,422 \mathrm{~kg}(44,500 \mathrm{lb} / 34,000 \mathrm{lb})$ \\
\hline Wheelbase & $7.44 \mathrm{~m}(293 \mathrm{in})$. \\
\hline Passenger capacity & $\begin{array}{l}37 \text { seats or } 33 \text { passengers with } 2 \text { wheelchair } \\
\text { positions; } 23 \text { standees }\end{array}$ \\
\hline Fuel cell manufacturer and model & Ballard FCvelocity-HD6 fuel cell power system \\
\hline Rated power & Fuel cell power system: $150 \mathrm{~kW}$ \\
\hline Hybrid type & Series, charge sustaining \\
\hline Drive system & Siemens ELFA, integrated by ISE \\
\hline Propulsion motor & $2-A C$ induction, $85 \mathrm{~kW}$ each \\
\hline & Battery: Valence, lithium phosphate, \\
\hline Energy storage & 2 packs, 16 batteries each \\
& Rated energy: $47 \mathrm{kWh}$ \\
\hline Accessories & Electrical \\
\hline Fuel storage & Eight roof mounted, Dynetek, type 3 tanks; \\
\hline Range & 5,000 psi rated; 56 kg hydrogen (useful) \\
\hline Bus purchase cost & $337-381$ km (210-237 miles) \\
\hline
\end{tabular}

The FCEBs have a fuel cell-dominant hybrid-electric propulsion system in a series configuration. In a series configuration, the fuel cell power system is not mechanically coupled to the drive axle. The $150 \mathrm{~kW}$ fuel cell power system and the $47 \mathrm{kWh}$ energy storage system work together to provide power to two $85 \mathrm{~kW}$ electric drive motors, which are coupled to the driveline through a combining gearbox. When the bus needs extra power, the fuel cell power system and energy storage system provide power to the drive motors. When the power requirements of the bus are low, the fuel cell power system provides power and recharges the energy storage system. The hybrid system is also capable of regenerative braking, which captures the energy typically expended during braking and uses it to recharge the energy storage system.

The power plant, which is the primary power source for the hybrid system, is Ballard Power Systems'150 kW FCvelocity-HD6. The energy storage system consists of two lithium phosphate

\footnotetext{
${ }^{5}$ Range calculations are based on the minimum and maximum monthly average fuel economy and useful fuel.
} 
battery packs from Valence. The Whistler buses required a supplemental $20 \mathrm{~kW}$ heater to meet winter heating demands.

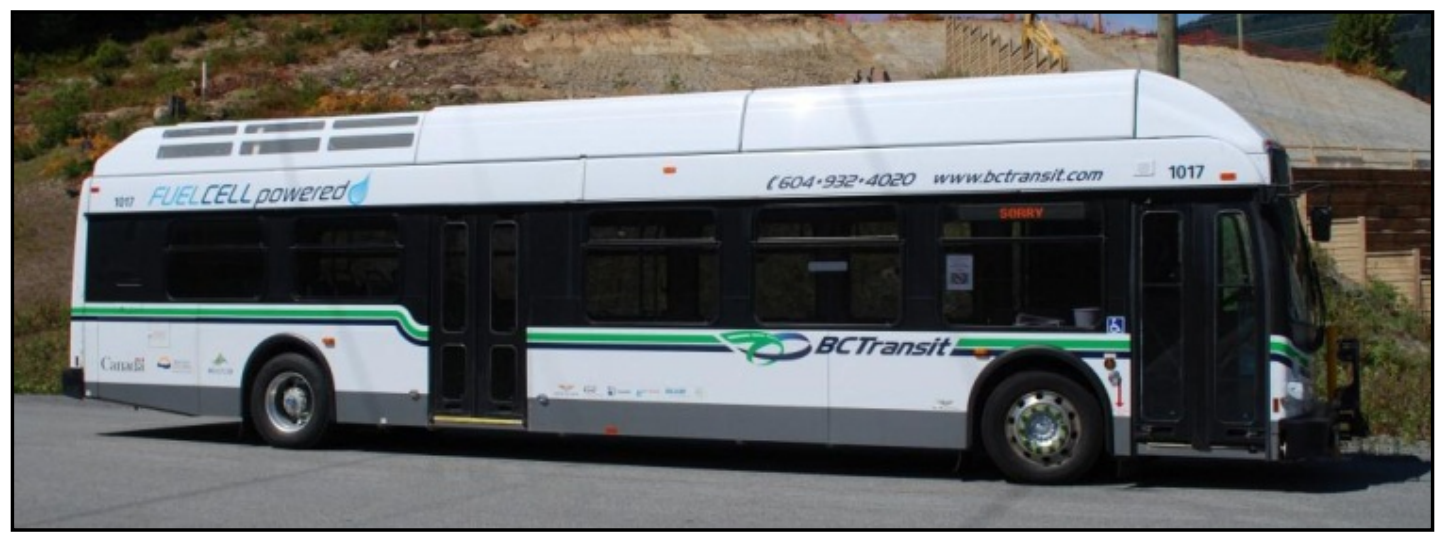

Figure 2. One of Whistler Transit's fuel cell buses

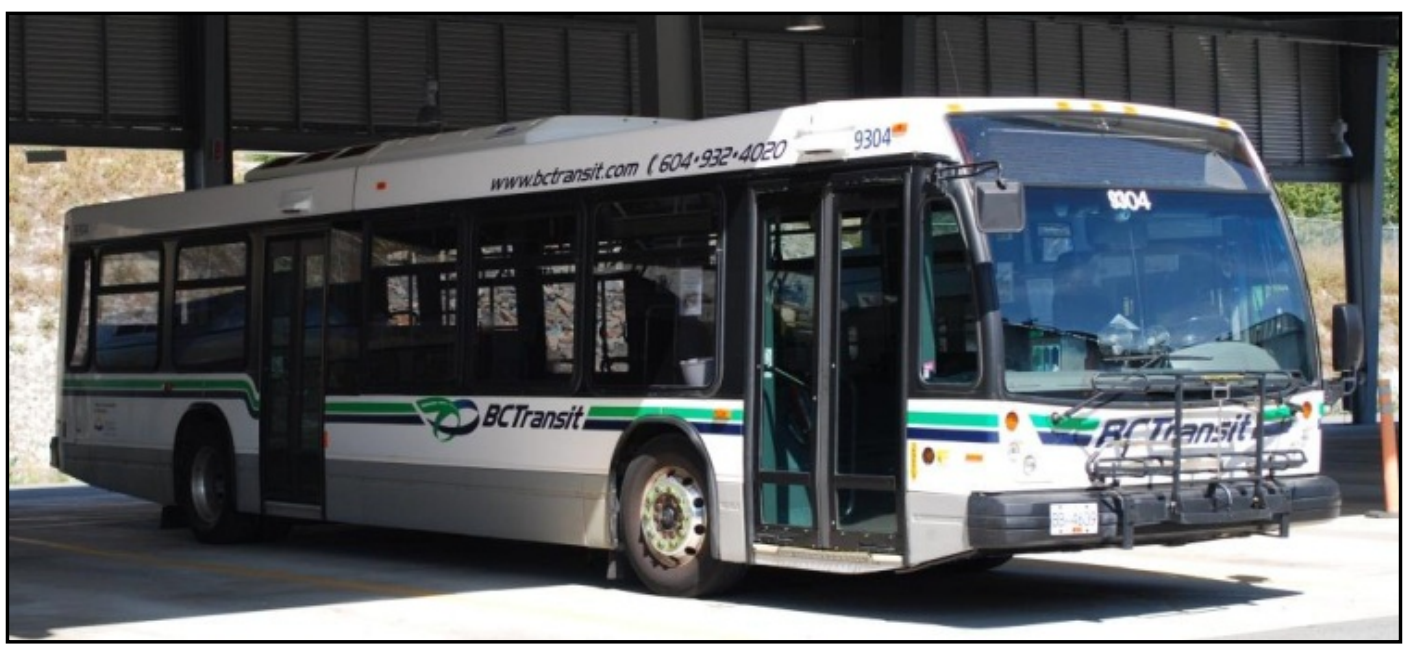

Figure 3. One of Whistler Transit's diesel buses

\section{FCEB Development Process-Technology Readiness Levels}

In its 2012 annual status report, ${ }^{6}$ NREL introduced a guideline for assessing the technology readiness level (TRL) for FCEBs. This guideline was developed using a Technology Readiness Assessment Guide ${ }^{7}$ published by DOE in September 2011. Table 2 provides a TRL guide tailored for the commercialization of FCEBs. The technology demonstration/commissioning phase that includes TRLs 6 through 8 begins the iterative process to validate the design, analyze the results, and reconfigure or optimize the design as needed. The manufacturer typically works with a transit agency partner to conduct in-service tests on the bus. Updates to the design are made based on the performance results, and the buses go back into demonstration and through

\footnotetext{
${ }^{6}$ Fuel Cell Buses in U.S. Transit Fleets: Current Status 2012, NREL/TP-5600-56406.

${ }^{7}$ DOE Technology Readiness Assessment Guide, G 143.3-4a, https://www.directives.doe.gov/directives/0413.3EGuide-04a/view.
} 
the cycle until the design meets the performance requirements. This can be a time-consuming process as manufacturers work through technical difficulties.

Table 2. Technology Readiness Levels for FCEB Commercialization

\begin{tabular}{|c|c|c|c|}
\hline $\begin{array}{c}\text { Relative Level of } \\
\text { Technology } \\
\text { Development }\end{array}$ & $\begin{array}{l}\text { Technology } \\
\text { Readiness } \\
\text { Level }\end{array}$ & TRL Definition & Description \\
\hline Deployment & TRL 9 & $\begin{array}{l}\text { Actual system } \\
\text { operated over the full } \\
\text { range of expected } \\
\text { conditions }\end{array}$ & $\begin{array}{l}\text { The technology is in its final form. } \\
\text { Deployment, marketing, and support begin } \\
\text { for the first fully commercial products. }\end{array}$ \\
\hline \multirow{3}{*}{$\begin{array}{l}\text { Technology } \\
\text { Demonstration/ } \\
\text { Commissioning }\end{array}$} & TRL 8 & $\begin{array}{l}\text { Actual system } \\
\text { completed and } \\
\text { qualified through test } \\
\text { and demonstration }\end{array}$ & $\begin{array}{l}\text { The last step in true system development. } \\
\text { Demonstration of a limited production of } 50 \\
\text { to } 100 \text { buses at a small number of } \\
\text { locations. Beginning the transition of all } \\
\text { maintenance to transit staff. }\end{array}$ \\
\hline & TRL 7 & $\begin{array}{l}\text { Full-scale validation in } \\
\text { relevant environment }\end{array}$ & $\begin{array}{l}\text { A major step up from TRL } 6 \text { by adding } \\
\text { larger numbers of buses and increasing the } \\
\text { hours of service. Full-scale demonstration } \\
\text { and reliability testing of } 5 \text { to } 10 \text { buses at } \\
\text { several locations. Manufacturers begin to } \\
\text { train larger numbers of transit staff in } \\
\text { operation and maintenance. }\end{array}$ \\
\hline & TRL 6 & $\begin{array}{l}\text { Engineering/pilot-scale } \\
\text { validation in relevant } \\
\text { environment }\end{array}$ & $\begin{array}{l}\text { First tests of prototype buses in actual } \\
\text { transit service. Field testing and design } \\
\text { shakedown of } 1 \text { to } 2 \text { prototypes. } \\
\text { Manufacturers assist in operation and } \\
\text { typically handle all maintenance. Begin to } \\
\text { introduce transit staff to technology. }\end{array}$ \\
\hline \multirow{2}{*}{$\begin{array}{l}\text { Technology } \\
\text { Development }\end{array}$} & TRL 5 & $\begin{array}{l}\text { Laboratory scale, } \\
\text { similar system } \\
\text { validation in relevant } \\
\text { environment }\end{array}$ & $\begin{array}{l}\text { Integrated system is tested in a laboratory } \\
\text { under simulated conditions based on early } \\
\text { modeling. System is integrated into an } \\
\text { early prototype or mule platform for some } \\
\text { on-road testing. }\end{array}$ \\
\hline & TRL 4 & $\begin{array}{c}\text { Component and } \\
\text { system validation in } \\
\text { laboratory environment }\end{array}$ & $\begin{array}{l}\text { Basic technological components are } \\
\text { integrated into the system and begin } \\
\text { laboratory testing and modeling of potential } \\
\text { duty cycles. }\end{array}$ \\
\hline \multirow[t]{2}{*}{$\begin{array}{l}\text { Research to Prove } \\
\text { Feasibility }\end{array}$} & TRL 3 & $\begin{array}{c}\text { Analytical and } \\
\text { experimental critical } \\
\text { function and/or proof of } \\
\text { concept }\end{array}$ & $\begin{array}{l}\text { Active research into components and } \\
\text { system integration needs. Investigate what } \\
\text { requirements might be met with existing } \\
\text { commercial components. }\end{array}$ \\
\hline & TRL 2 & $\begin{array}{c}\text { Technology concept } \\
\text { and/or application } \\
\text { formulated } \\
\end{array}$ & $\begin{array}{l}\text { Research technology needed to meet } \\
\text { market requirements. Define strategy for } \\
\text { moving through development stages. }\end{array}$ \\
\hline $\begin{array}{l}\text { Basic Technology } \\
\text { Research }\end{array}$ & TRL 1 & $\begin{array}{c}\text { Basic principles } \\
\text { observed and reported }\end{array}$ & $\begin{array}{l}\text { Scientific research and early development } \\
\text { of FCEB concepts. }\end{array}$ \\
\hline
\end{tabular}


Figure 4 provides a graphic representation of this process. NREL considers the BC Transit FCEBs to be at TRL 7 because the design of the bus was led by manufacturers experienced with FCEB development and the deployment includes the 20-bus BC Transit fleet. These buses represent a full-scale validation in a relevant environment.

\section{Commercialization Process}

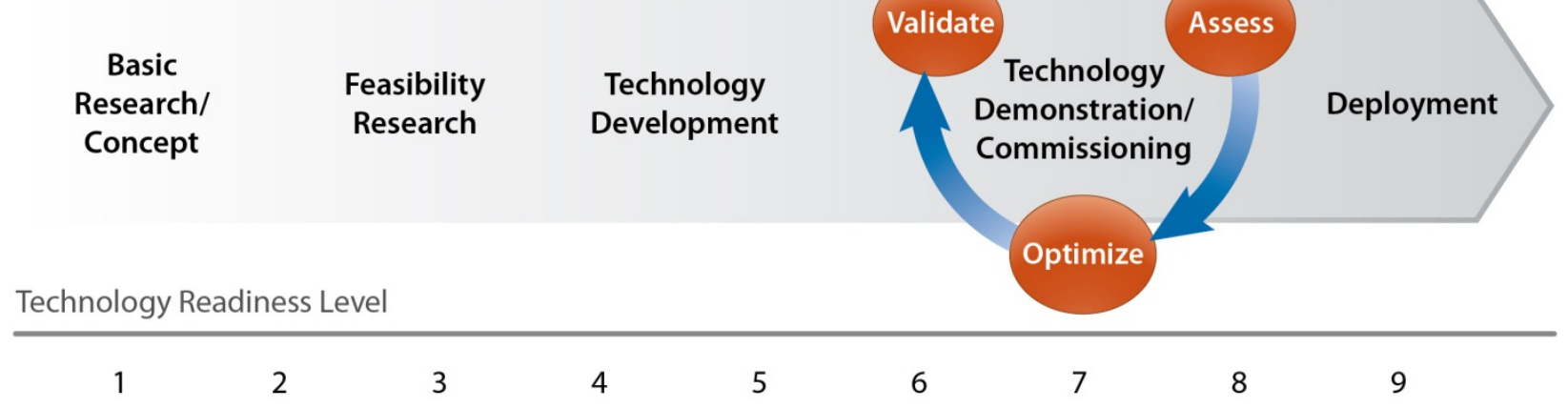

Figure 4. Graphic representation of the commercialization process developed for FCEBs 


\section{Fueling and Maintenance Facilities}

As part of the program, Air Liquide built a hydrogen station in Whistler. As part of constructing a new maintenance facility, BC Transit included upgrading the building for safe use of hydrogen-fueled buses. This section describes the station and provides a summary of fueling data from April 2011 through March 2013.

\section{Air Liquide Hydrogen Station}

Fueling a 20-bus FCEB fleet requires a station capable of dispensing a significant amount of hydrogen - up to $800 \mathrm{~kg}$ per day when the entire fleet is operating. BC Transit used a typical bid process to select the fuel supplier. The agency released a request for proposals that outlined the specific needs for the station. After reviewing the proposals, BC Transit contracted with Air Liquide to build, maintain, and operate a station for the demonstration. The buses are fueled by Whistler Transit staff. The station is a liquid hydrogen storage and gaseous dispensing station and is designed to fast-fill up to 20 buses per day. The station (shown in Figure 5) includes the following equipment:

- Two liquid hydrogen storage tanks - approximately10,000 kg total

- Three liquid hydrogen pumps

- Vaporizer

- Dispenser with two hoses

- High pressure gaseous storage bank

- Control system container

- Remote monitoring.

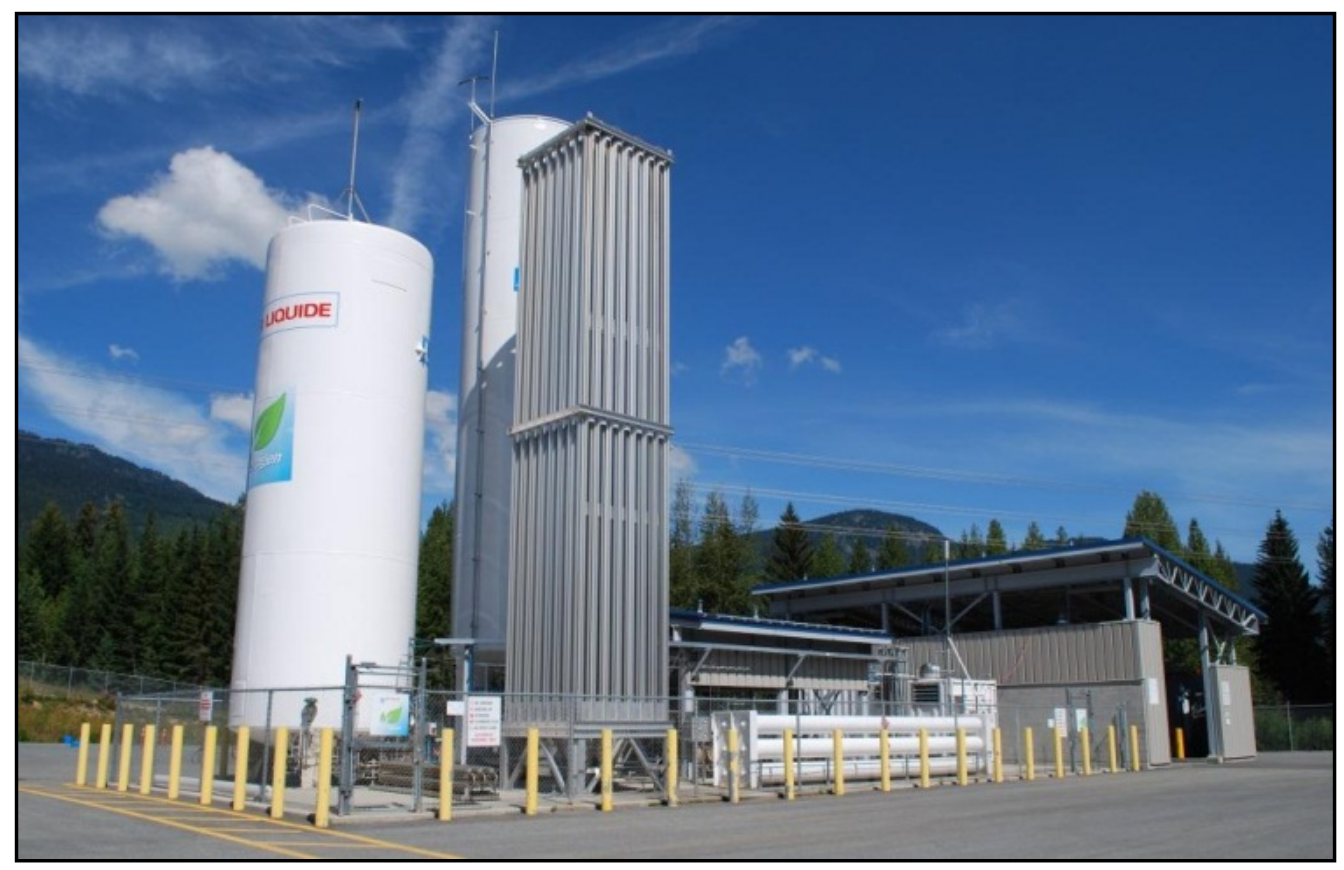

Figure 5. Air Liquide hydrogen station at Whistler Transit Centre 
A liquid hydrogen station best fit the $\mathrm{BC}$ Transit requirements and required a footprint that was reasonable given the property limits of the facility. Obtaining liquid hydrogen provided a challenge because of the distance between Whistler and Air Liquide's nearest production facility in Becancour, Quebec. At a distance of 4,650 kilometers (2,889 miles) it takes up to three days for a tanker to deliver hydrogen to the site. Because of the logistics, the station was designed with two liquid hydrogen tanks to ensure sufficient on-site hydrogen to fuel the buses. Also, two tanker trucks are used to allow a delivery each week. Figure 6 shows one of the tanker trucks ready to fill the station with liquid hydrogen.

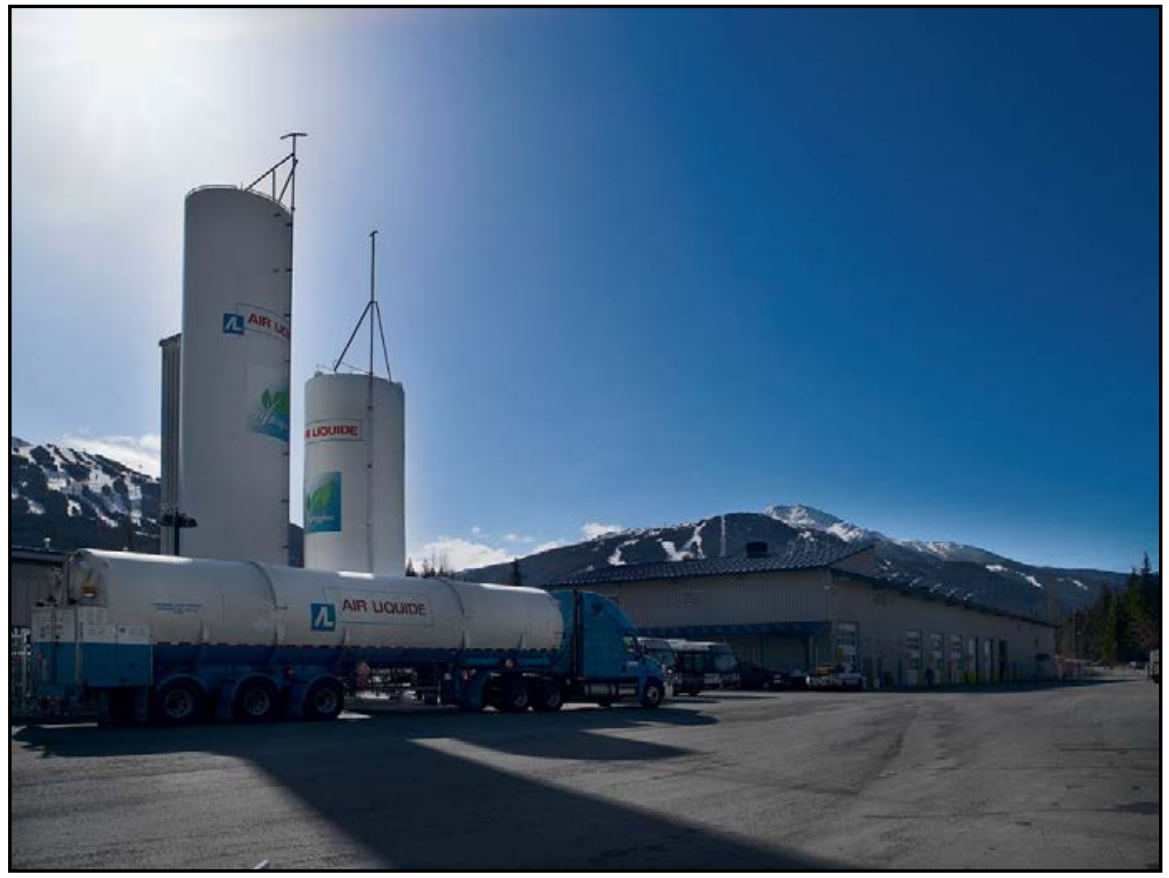

Figure 6. A delivery tanker fills the Whistler Transit station with liquid hydrogen. Photo courtesy of Air Liquide

The Quebec plant produces hydrogen using renewable methods - through electrolysis of water and using a chlor alkali waste recuperation process. Power for these processes comes from the local electric grid, which is $98 \%$ hydro-electric or other renewable sources. This was important for BC Transit in evaluating proposed fueling solutions for the fleet including full life cycle analysis of the greenhouse gases produced during hydrogen generation, delivery, and use. BC Transit used the model GHGenius, ${ }^{8}$ which was developed for Natural Resources Canada. Even with the logistics of trucking this hydrogen across Canada, the agency estimates it reduces greenhouse gas emissions by $62 \%$ compared to what it would have with a diesel fleet.

Construction on the station was completed in November 2009. BC Transit set the following goals for the station:

- Achieve a full fill $(\sim 45 \mathrm{~kg})$ in 10 minutes

- Fill up to 18 buses sequentially

- Demonstrate $100 \%$ reliability during the fueling window.

\footnotetext{
${ }^{8}$ www.ghgenius.ca/about.php
} 
The station cost reported by Air Liquide was approximately $\$ 6$ million (CAD), not including the cost of land and civil work needed to prepare the site. This cost is likely more than that of a similar station because of the need for additional hydrogen storage specific to this site (to account for the logistics of transporting from Quebec). BC Transit's original maintenance contract with Air Liquide was for five years to cover the planned demonstration.

Figure 7 shows a basic schematic of the station and primary components. There are three liquid pumps, two of which are required for operation. The third pump builds in redundancy to avoid station downtime.

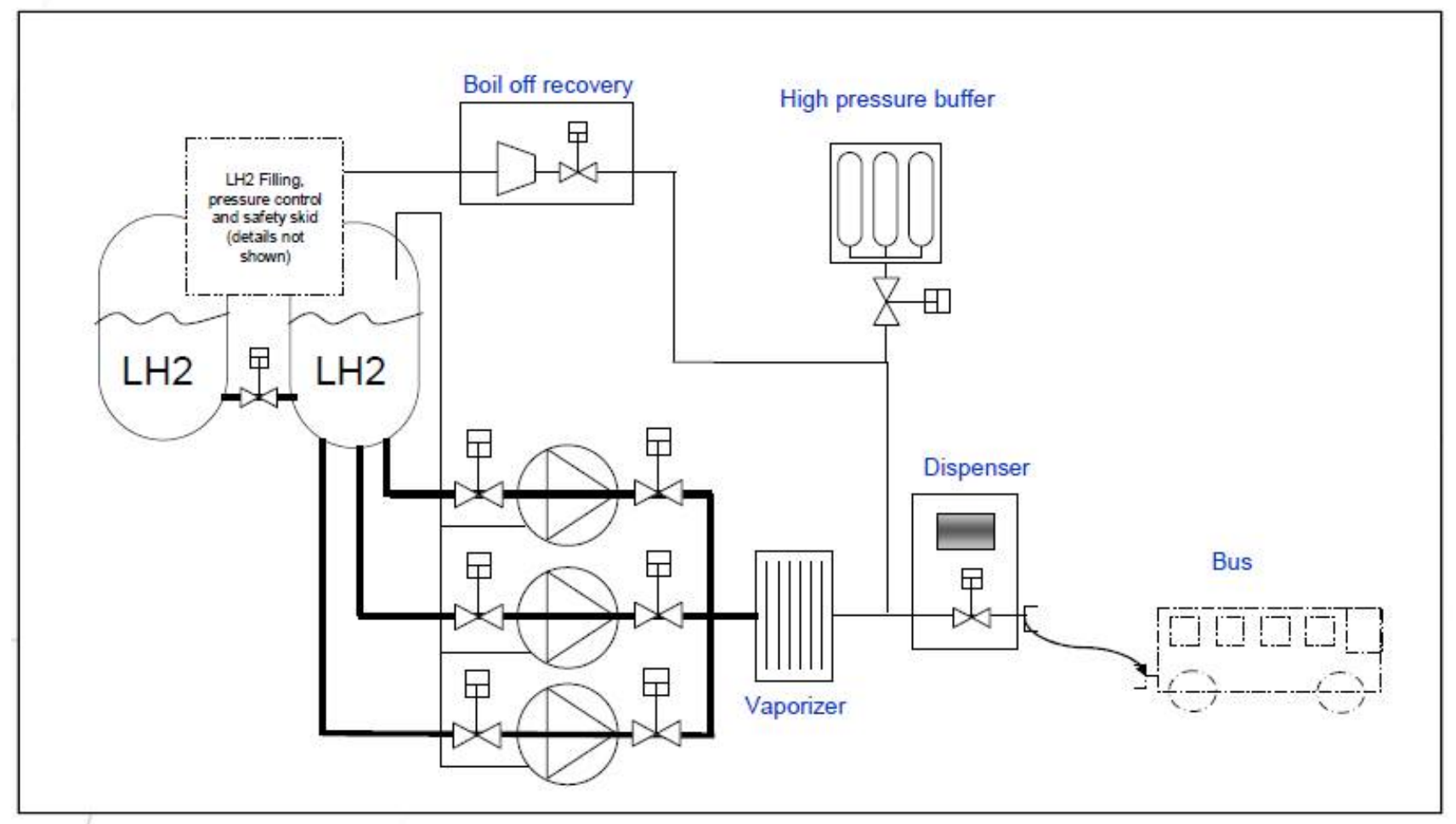

Figure 7. Block diagram of the Air Liquide station. Diagram courtesy of Air Liquide 
The dispenser (see Figure 8) is equipped with two hoses. Hydrogen losses are inherent in any liquid hydrogen station (as with liquid natural gas) and come from boil-off, transfer between storage tanks, and the cooling process of the pumps during fueling. To minimize these losses, the station is configured to capture boil-off from the storage tanks in the gaseous buffer tanks. If the buffer is full, the excess hydrogen is vented. For this demonstration, the primary losses identified by Air Liquide are due to on-site storage tank boil-off and transfer from one tank to the other. Fuel losses during transport from Quebec also occurred but are considered minor compared to the on-site losses.

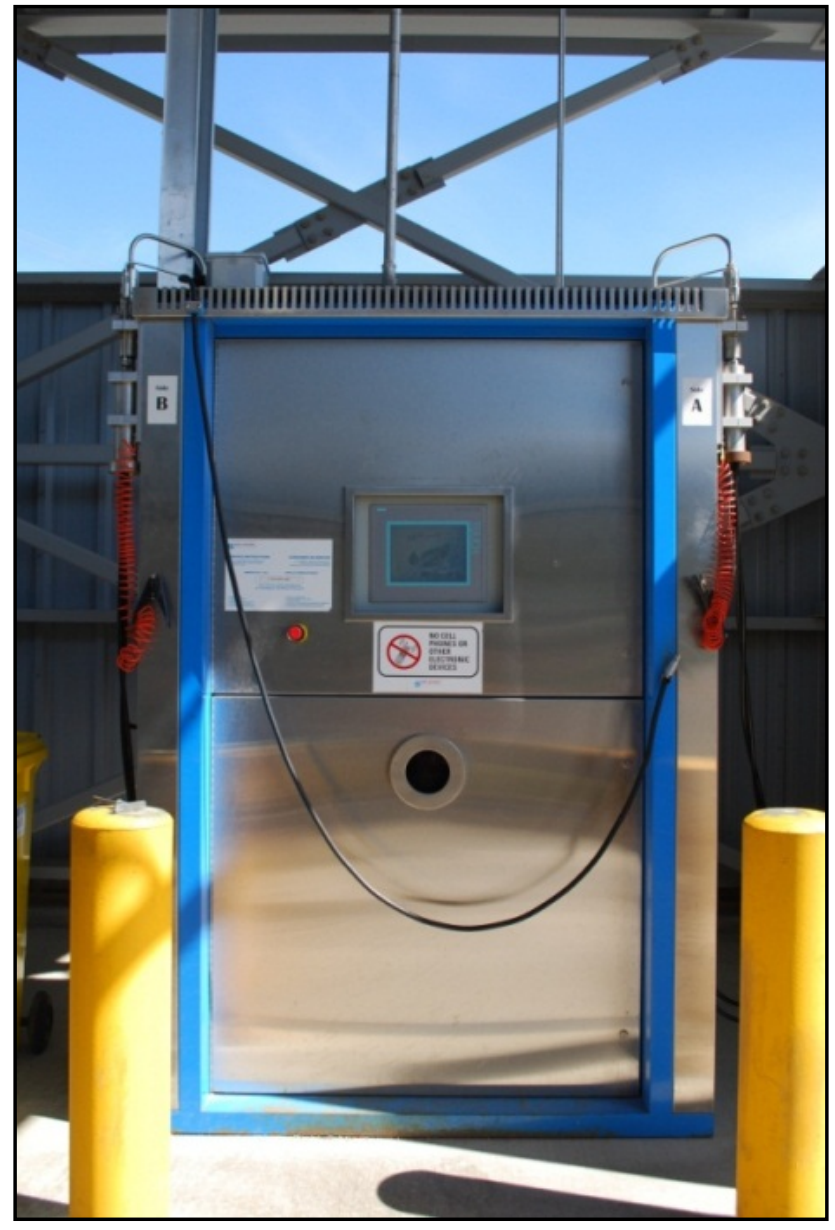

Figure 8. Hydrogen dispenser

\section{Maintenance Facilities}

When the project was being planned, $\mathrm{BC}$ Transit was in the process of expanding service in Whistler and required a larger facility. Senior Government funding for the FCEB project provided for the maintenance bays to be equipped for safe handling of hydrogen. In addition to increased air flow and hydrogen sensors, each maintenance bay is equipped with vent lines that are connected to a bus's hydrogen system while it is parked inside. This cost was estimated at $\$ 680,000$ (CAD). The capability to maintain hydrogen buses was built into the facility as it was constructed and this cost is not necessarily comparable to what would be required to upgrade an existing facility. Figure 9 shows the maintenance facility, which has six bays for maintaining the buses. Figure 10 shows the interior of the facility. 


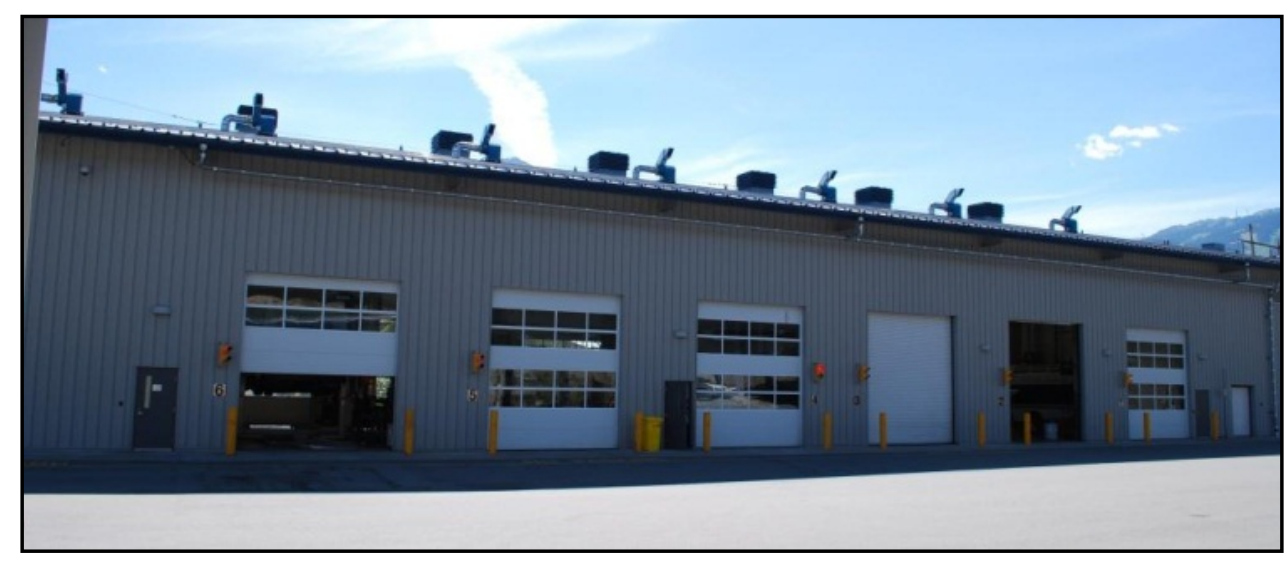

Figure 9. Whistler Transit maintenance facility

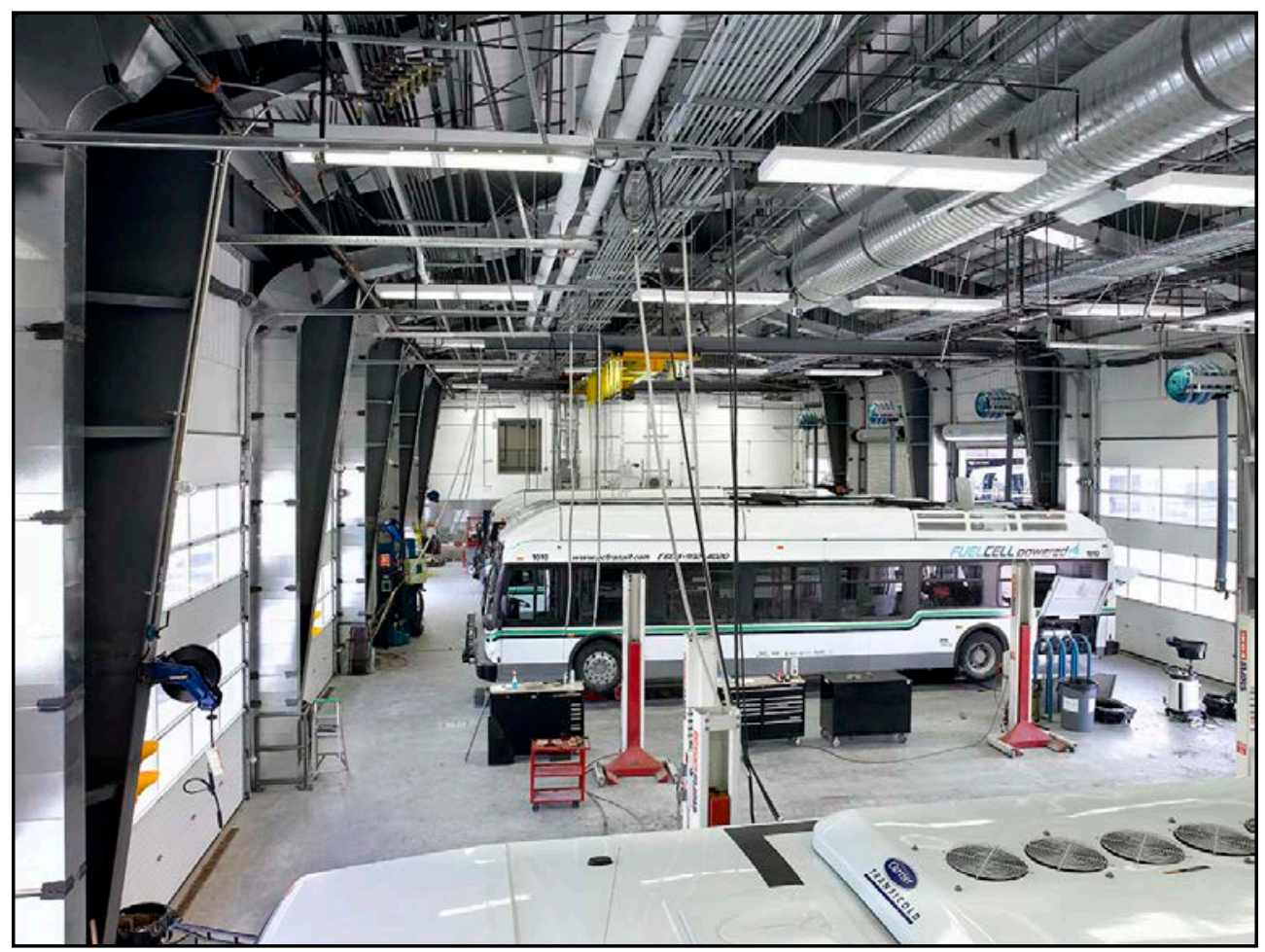

Figure 10. Maintenance facility. Photo courtesy of BC Transit

Figure 11 shows the outdoor bus storage area at the Whistler Transit Centre. The canopy is equipped to allow the buses to be plugged in during cold weather. This is to keep the fuel cells from freezing - it does not charge the batteries. 


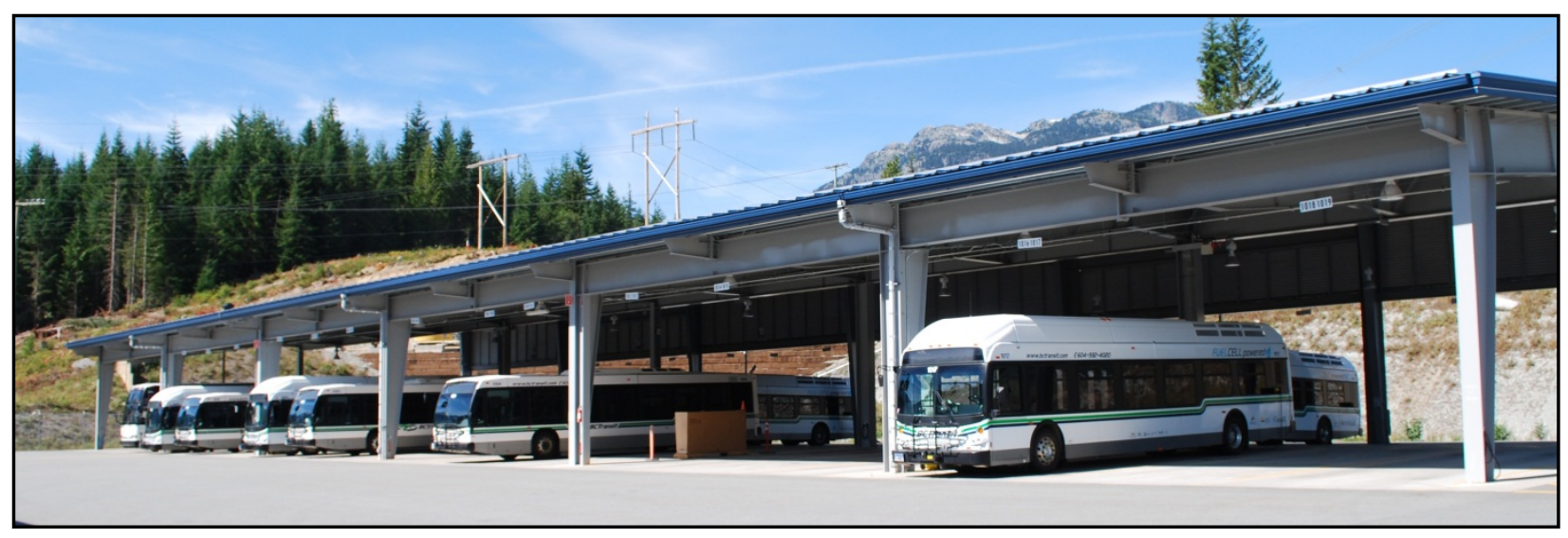

Figure 11. Bus storage area at Whistler Transit

This report is available at no cost from the National Renewable Energy Laboratory (NREL) at www.nrel.gov/publications. 


\section{Implementation Experience}

BC Transit used a standard procurement process to purchase the FCEBs. The agency released a request for proposals in February 2007 outlining bus specifications to meet the service requirements of Whistler. The FCEB project was planned in two phases:

- Phase 1: Pre-production bus design, testing, and validation

- Phase 2: Production buses final design, manufacture, and operation.

After reviewing the proposals, BC Transit selected New Flyer Industries to supply the preproduction bus to be used to validate the design and operating performance. This pre-production bus - or pilot bus - would be the basis for the production buses. New Flyer subcontracted with ISE Corporation for hybrid system design and integration and with Ballard Power Systems for the fuel cell power system.

\section{Pilot Bus Testing}

The pilot bus was delivered to BC Transit in Victoria on September 22, 2008. ISE conducted the initial commissioning and testing of the bus in San Diego, California, prior to shipping the bus to Victoria. Once the bus was delivered to BC Transit, an evaluation team conducted a 30-day evaluation of the bus with a goal of determining whether the bus was suitable for full transit operations and to identify issues that would need to be modified for the production buses. During testing, the evaluation team operated the bus in two shifts per day, driving around Victoria on regular transit routes. The bus was loaded with sandbags and water jugs to simulate passenger loads. During each shift, a BC Transit driver would operate the bus, and a BC Transit engineer and at least one technician from one of the manufacturers would monitor the performance. The $\mathrm{BC}$ Transit engineer logged any faults that occurred. If possible, the manufacturer technician corrected the fault as it was encountered. During the evaluation, the bus was driven to Whistler, operated over some of the more demanding routes, and driven back to Victoria.

The bus was driven an average of 309 kilometers (192 miles) per day during the test for a total of 8,650 kilometers $(5,375$ miles $)$ and more than 300 hours. The reported fuel consumption averaged 8.35 kilograms per 100 kilometers $(\mathrm{kg} / 100 \mathrm{~km})$, which equates to approximately 8.4 miles per diesel gallon equivalent (mi/DGE). The pilot bus testing took place mostly in Victoria where conditions are not as harsh as that of the Whistler area. At the end of the 30-day test, BC Transit determined that the bus met the minimum performance criteria but identified a number of key issues to address for the production buses.

The pilot bus was also tested in a cold chamber at specified ambient temperatures down to $-20^{\circ} \mathrm{C}$. The cold chamber is located in Ottawa, Ontario, at the National Research Council Canada's Surface Transportation facilities. ${ }^{9}$ The tests were done to address potential noncompliance issues related to cold weather operating performance and to identify necessary design changes or other mitigating actions prior to building the production buses. Tests were conducted on the following systems:

1. On-road emergency fuel cell module freeze protection system

\footnotetext{
${ }^{9}$ http://www.nrc-cnrc.gc.ca/eng/solutions/facilities/surface_transportation/environmental_chamber.html.
} 
2. Interior coach heating, dehumidification, and windshield defrosting

3. Thermal management and operation of Valence batteries

4. Thermal management of fuel cell module coolant loop and cold-start reliability.

Once all testing on the pilot bus was completed, BC Transit outlined key issues that required modifications prior to building the production buses.

\section{Service Starts During the 2010 Winter Olympics}

BC Transit planned to have the buses operating in time to be showcased at the 2010 Winter Olympic Games held in Vancouver and Whistler. Plans began well in advance of this event; however, new technology development can take significantly more time than procurement of a standard bus technology. The manufacturers worked through several issues and challenges to meet this deadline. The first bus was delivered in November 2009 and the final bus arrived in January 2010. The buses were successfully introduced during the Olympics through major support from the manufacturer partners.

One major challenge involved changes to the energy storage system. The original battery manufacturer was acquired by an automotive original equipment manufacturer that then discontinued its heavy duty product, forcing ISE to change vendors and modify the hybrid system to accommodate the new battery packs. Then in early 2010, ISE became insolvent and a portion of the company and technology was purchased by Bluways. Technical support for the hybrid system diminished significantly, and eventually New Flyer and Ballard stepped up their level of support for the fleet.

\section{Whistler Transit Operations}

After the Olympic debut, Whistler Transit placed the FCEBs into normal operation in the Whistler/Blackcomb service area. As mentioned previously, the FCEBs make up the majority of the fleet at Whistler and represent a true test of how the technology can be integrated into transit operations. At the beginning of the demonstration, the manufacturers provided training and support to Whistler Transit while staff became familiar with the operation and maintenance of the buses. Over time, the agency staff has assumed responsibility for the majority of maintenance on the buses with occasional support from Ballard and New Flyer.

As it serves a resort municipality, Whistler Transit's service varies throughout the year with the heaviest use occurring during the peak of the winter season. During that time, the agency needs a maximum number of buses to meet service demands and brings in additional diesel buses to accommodate the need for mid-day fueling for some of the FCEBs. The duty cycle and conditions are challenging. Average temperature ranges from a low of $-8^{\circ} \mathrm{C}\left(17.6^{\circ} \mathrm{F}\right)$ up to a high of $27^{\circ} \mathrm{C}\left(80.6^{\circ} \mathrm{F}\right)$ but the temperature can occasionally drop to $-25^{\circ} \mathrm{C}\left(-13^{\circ} \mathrm{F}\right)$ and rise to $35^{\circ} \mathrm{C}\left(95^{\circ} \mathrm{F}\right)$ for short durations. Heavy passenger loading with added weight from ski gear, cold temperatures, icy roads, melting snow, and high road grades tests the FCEBs in one of the harshest settings in the province. In summers the passenger loading drops, requiring fewer buses to meet service demands.

Early in the demonstration, the agency determined that the range of the FCEBs was not sufficient for all-day operation on the commuter route to the local community of Pemberton and the buses 
had difficulties with the long hilly terrain (insufficient power). As a result they were not able to meet the service schedule. For those reasons, the FCEBs are operated on all but the commuter runs. The buses leave the Transit Centre in the morning and some buses return for a mid-day fueling before operating on the afternoon shift. At the end of the day, the buses are fueled again and prepped for the next day's service.

\section{Summary of Achievements and Challenges to Date}

This section focuses on the achievements and challenges of BC Transit and its partners in implementing operation of the FCEB fleet. As with all new technology development, there have been many lessons learned that can be used by other agencies considering FCEB technology. From BC Transit's perspective, there have been many achievements for the demonstration, including the following:

- The project was delivered on-time and on-budget.

- The FCEBs have accumulated more than 3 million kilometers in revenue service, operating up to 22 hours a day in a wide range of temperatures.

- By operating the FCEBs, the agency has avoided emitting more than 4,400 tons of $\mathrm{CO}_{2}$ compared to operating diesel buses.

- The FCEBs form the backbone of the fleet -20 of 23 buses or 26 during peak season.

- The FCEBs have been incorporated into the fleet and are fully supported by Whistler Transit staff.

- The hydrogen station has operated reliably with few issues, none of which resulted in downtime for the buses.

- The station has dispensed more than 462,000 kilograms of fuel over 17,900 fills without a safety incident.

- The FCEBs have been accepted by the drivers, passengers, and the local community.

The challenges and lessons learned so far include bus-related problems and programmatic issues, as well as market developments that can cause a ripple effect for the entire fuel cell bus industry. The remainder of this section outlines some of the issues encountered during the demonstration.

Bus range - While the original design included eight hydrogen tanks, the number of tanks on the production buses was reduced to six because of weight considerations. Once the buses went into service, $\mathrm{BC}$ Transit determined that the performance would not meet the service requirements. Early in the demonstration, the manufacturer added the two tanks back to each bus. In addition, Whistler Transit added a mid-day fueling to the operation to ensure that the buses could operate all day. This has required the agency to hire more staff to fuel the buses. This mid-day fueling was only required for a few specific routes.

Bus suspension-The buses have had issues with the suspension because of the weight and the difficult duty cycle. Components within the suspension, such as sway bars, have experienced higher wear and tear compared to similar components on conventional buses. To address the issue of early failures, Whistler Transit has added these components to its parts inventory and is integrating replacements into the normal preventive maintenance schedule. 
Battery issues - The batteries have had issues that have been addressed with a routine procedure to balance the packs. Whistler Transit uses a Brusa charger for this procedure, which can take a few hours to a few days. This takes a bus out of service for the duration of the charging time and also takes up space in the facility.

Air compressor/motor/controller-The air compressor, motor, and controller assembly, which is part of the fuel cell balance of plant, has proved to be one of the biggest issues for the system. Ballard is currently testing another compressor and plans to handle this component as part of its system for future buses.

Fuel cell lifetime - In its early experience with FCEB demonstrations, Ballard determined that it could lengthen the life of the fuel cell stack by periodically performing a dry-out procedure. For $\mathrm{BC}$ Transit, this required removing the module and shipping it to Ballard for the procedure. The demonstration project has two spare fuel cell modules, so this could be done without taking a bus out of service for an extended time. Currently, this procedure is done at Whistler Transit without removing the fuel cell from the bus. Ballard is working on a process to incorporate the dry-out process into the module operation so that it is transparent to the customer.

Delivery schedule - Planning any new bus procurement can take more time than anticipated. This is especially true for advanced technology buses. BC Transit planned to roll out its FCEB fleet during the 2010 Olympics, and this was a date that could not be moved if the buses took longer to develop and build. The partners met the target; however, the buses had not been fully optimized. The demonstration was successful, but it took a significant number of technical staff from the manufacturers to ensure that all went as planned. Once the buses were delivered to Whistler for regular operations, it took additional time for the manufacturers to modify the buses. $\mathrm{BC}$ Transit estimates that the first year and a half of the demonstration was dedicated to addressing issues that might not have been necessary if the team had sufficient time to work out the bugs prior to launch.

Changing market players - The current economic climate has resulted in changing players within the FCEB market. Over the years, several companies have left the market through restructuring or bankruptcy. The departure of ISE left the project team with insufficient support for the demonstration. The company's demise affected other FCEB demonstrations as well. When the partners no longer provide technical support or produce parts needed for repair, this makes conducting long-term demonstrations a challenge.

Evolution of technology and components - As the technology development progresses, components and parts are modified for new designs. This evolution results in components that are now obsolete for current demonstrations. Replacement parts become hard to locate or may become obsolete because manufacturers have stopped producing the older designs. Obtaining replacement battery modules has proved to be challenging for $\mathrm{BC}$ Transit because the manufacturer's new battery design is not the same size or does not have the same operating characteristics. 


\section{Evaluation Results}

From the time the buses were deployed through March 2013, the FCEBs have operated more than 3 million kilometers and the fuel cell power plants have accumulated more than 157,000 hours. The results presented in this section cover two years of FCEB operations from April 2011 through March 2013. By this time period, the buses were fully integrated into the fleet and were operating in typical service at Whistler Transit. The time periods prior to this were considered developmental; the manufacturers were still making modifications to the buses' systems to optimize performance. These early data are not included in the calculations presented in this report.

\section{FCEB Route Assignments}

Whistler Transit operates the FCEB and diesel bus fleet on eight fixed routes in the Whistler/Blackcomb area. The diesel buses are used primarily as a fill-in when the FCEBs are out of service for maintenance. Because the diesel buses and FCEBs are not used in similar service, a direct comparison is not necessarily accurate - especially when comparing fuel economy. BC Transit has provided averages for diesel buses within its fleet that operate in a duty cycle more similar to that of the FCEBs. NREL has included those averages where appropriate for comparison to a baseline.

\section{Bus Use and Availability}

Bus use and availability are indicators of reliability. Lower bus usage may indicate downtime for maintenance or purposeful reduction of planned work for the buses. This section summarizes bus usage and availability for the FCEBs.

BC Transit and Whistler Transit provided bus odometer data from several sources including fueling records and maintenance work orders. Data from these sources were manually entered and are subject to human error. British Columbia's carbon neutral regulation requires all public sector organizations (including BC Transit) to measure, reduce, and, where regulated, offset greenhouse gas (GHG) emissions from buildings, vehicle fleets, and paper use. BC Transit reports its annual carbon emissions to the Pacific Carbon Trust (PCT). ${ }^{10}$ The BC government set up the PCT as part of the Climate Action Plan to reduce GHG emissions in the province. The BC Transit Low Carbon and Electric Vehicle Offset Project-GHG Project Plan ${ }^{11}$ details offsets associated with the replacement of diesel buses in service on Whistler Transit routes with buses that use lower-GHG-emitting fuels (such as hydrogen). The Public Transit Offset Protocol and the Project Plan provide a route to quantifying, standardizing, and certifying emissions reductions enabled through fuel efficiency and fuel switching activities by Public Transit bodies. The resulting offsets may be sold as a commodity to create revenue for the Public Transit bodies, allowing them to make the decision to undertake a lower-GHG-emitting track, where business as usual would have maintained a higher-emissions status quo.

\footnotetext{
${ }^{10}$ Pacific Carbon Trust website: http://www.pacificcarbontrust.com/.

${ }^{11}$ The project plan and validation and verification reports are available at the Markit Environmental Registry: http://mer.markit.com/br-reg/public/project.jsp?project id=100000000000957.
} 
During the reporting process, the data are validated using all sources within the agency. NREL's analysis of the raw data was within $3 \%$ to $5 \%$ of the numbers reported to PCT. The analysis in this report uses the kilometers as reported to the PCT.

Table 3 summarizes the average monthly distance traveled in kilometers and miles for the FCEBs for the two-year data period. During this period, the buses traveled more than 2.1 million kilometers (1.3 million miles) for a monthly average per bus of 4,422 kilometers (2,748 miles).

Table 3. Average Monthly Distance Traveled (Evaluation Period)

\begin{tabular}{|c|c|c|c|c|c|c|c|}
\hline Bus & $\begin{array}{c}\text { Total } \\
\text { Kilometers } \\
\mathbf{4 / 1 1 - 3 / 1 2}\end{array}$ & $\begin{array}{c}\text { Total } \\
\text { Kilometers } \\
\mathbf{4 / 1 2 - 3 / 1 3}\end{array}$ & $\begin{array}{c}\text { Total } \\
\text { Kilometers }\end{array}$ & $\begin{array}{c}\text { Total } \\
\text { Miles }\end{array}$ & Months & $\begin{array}{c}\text { Monthly } \\
\text { Average } \\
\text { Kilometers }\end{array}$ & $\begin{array}{c}\text { Monthly } \\
\text { Average } \\
\text { Miles }\end{array}$ \\
\hline 1000 & 45,278 & 45,295 & 90,573 & 56,279 & 24 & 3,774 & 2,345 \\
\hline 1001 & 45,611 & 50,460 & 96,071 & 59,696 & 24 & 4,003 & 2,487 \\
\hline 1002 & 62,080 & 53,887 & 115,967 & 72,059 & 24 & 4,832 & 3,002 \\
\hline 1003 & 47,530 & 56,787 & 104,317 & 64,820 & 24 & 4,347 & 2,701 \\
\hline 1004 & 57,791 & 56,753 & 114,544 & 71,174 & 24 & 4,773 & 2,966 \\
\hline 1005 & 61,342 & 48,887 & 110,229 & 68,493 & 24 & 4,593 & 2,854 \\
\hline 1006 & 54,749 & 59,526 & 114,275 & 71,007 & 24 & 4,761 & 2,959 \\
\hline 1007 & 61,551 & 40,100 & 101,651 & 63,163 & 24 & 4,235 & 2,632 \\
\hline 1008 & 47,837 & 54,035 & 101,872 & 63,300 & 24 & 4,245 & 2,638 \\
\hline 1009 & 55,345 & 67,942 & 123,287 & 76,607 & 24 & 5,137 & 3,192 \\
\hline 1010 & 43,375 & 60,652 & 104,027 & 64,639 & 24 & 4,334 & 2,693 \\
\hline 1011 & 51,046 & 59,455 & 110,501 & 68,662 & 24 & 4,604 & 2,861 \\
\hline 1012 & 48,809 & 60,890 & 109,699 & 68,164 & 24 & 4,571 & 2,840 \\
\hline 1013 & 49,109 & 55,026 & 104,135 & 64,706 & 24 & 4,339 & 2,696 \\
\hline 1014 & 39,454 & 48,927 & 88,381 & 54,917 & 24 & 3,683 & 2,288 \\
\hline 1015 & 55,787 & 52,470 & 108,257 & 67,268 & 24 & 4,511 & 2,803 \\
\hline 1016 & 48,234 & 47,111 & 95,345 & 59,245 & 24 & 3,973 & 2,469 \\
\hline 1017 & 54,320 & 55,146 & 109,466 & 68,019 & 24 & 4,561 & 2,834 \\
\hline 1018 & 48,561 & 61,906 & 110,467 & 68,641 & 24 & 4,603 & 2,860 \\
\hline 1019 & 46,238 & 63,149 & 109,387 & 67,970 & 24 & 4,558 & 2,832 \\
\hline Total & $\mathbf{1 , 0 2 4 , 0 4 7}$ & $\mathbf{1 , 0 9 8 , 4 0 4}$ & $\mathbf{2 , 1 2 2 , 4 5 1}$ & $\mathbf{1 , 3 1 8 , 8 3 0}$ & $\mathbf{4 8 0}$ & $\mathbf{4 , 4 2 2}$ & $\mathbf{2 , 7 4 8}$ \\
\hline
\end{tabular}

Figure 12 charts the average distance traveled by month for the fleet in kilometers and miles. The general target of 3,000 miles per month is included as a line on the chart (the target of 3,000 miles per month is a general target for U.S transit buses and does not reflect a goal for BC Transit). The figure clearly shows the seasonal nature of the service in Whistler, with the highest monthly distance traveled during the winter months and the lower averages during the summer months. During peak season, the fleet's monthly average mileage exceeds the target. 


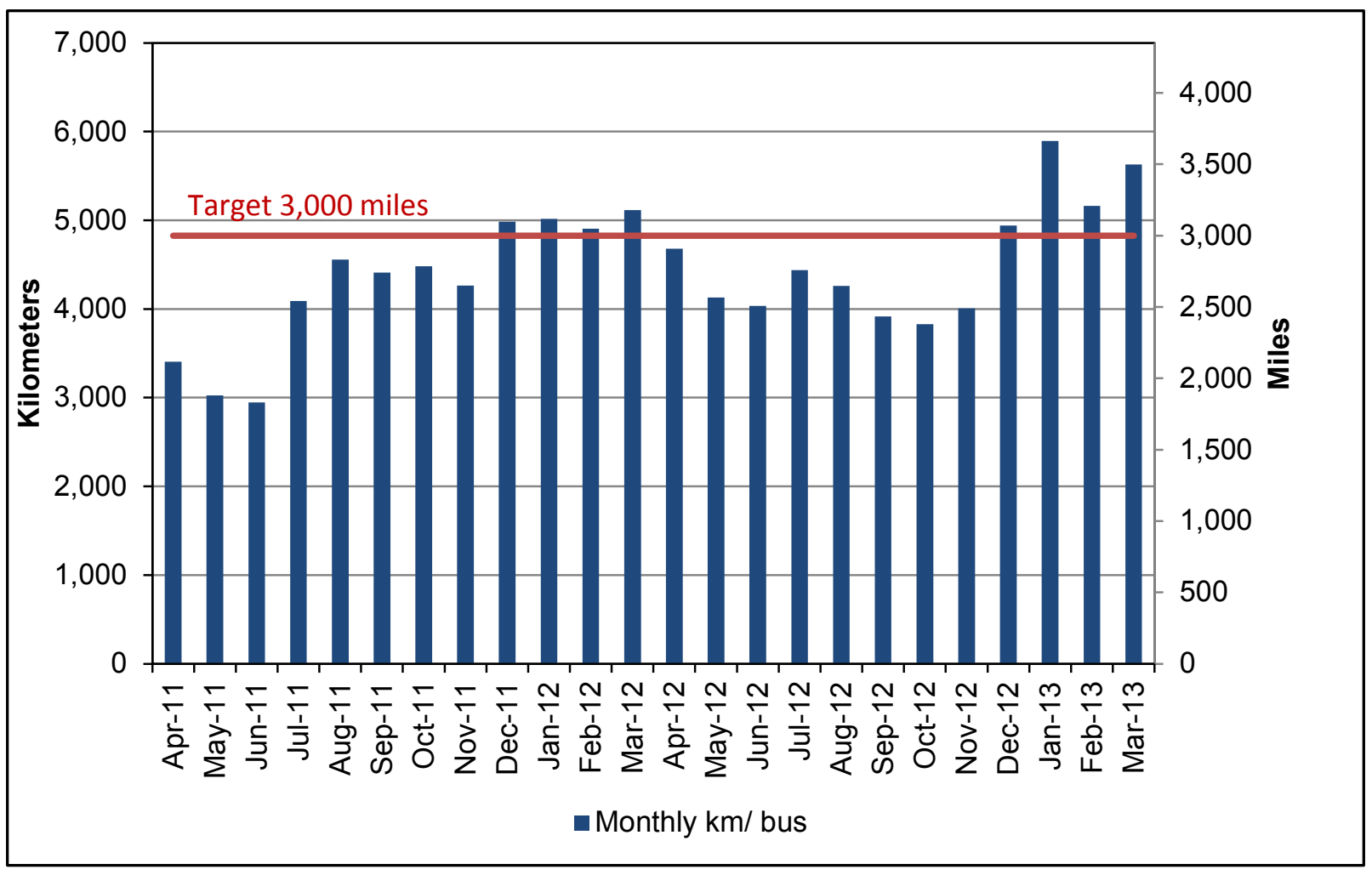

Figure 12. Average distance traveled by month

Another measure of reliability is availability - the percentage of days the buses are actually available for service out of days that the buses are planned for operation. For the BC Transit FCEB fleet, the buses are planned to operate every day, including weekends. To calculate daily availability, NREL used the daily bus allocation sheets provided by Whistler Transit. These daily allocation sheets provide a history of which buses were scheduled for service, which buses were available as spares, and which buses failed in service (roadcall). Because the daily allocation sheets have been filed as paper records, not all the sheets were available for analysis. Whistler Transit provided approximately $73 \%$ of the daily allocation sheets, which is considered to be a sufficient sample size to be representative of the total.

The data presented are based on availability for morning pull-out and don't necessarily reflect all-day availability. Figure 13 shows the monthly availability for the FCEBs during the two-year period. The target of $85 \%$ is included as a dashed line. Average monthly availability ranged from a low of $58 \%$ up to a high of $80 \%$. The overall average availability for the period was $69 \%$. Overall availability for each bus varies from $54 \%$ up to $78 \%$.

The daily bus allocation sheets track available buses but do not indicate the reasons why a bus is not available. Because of this, a categorization of unavailability reasons is not possible. NREL has included a breakdown of labor hours by category later in the analysis to indicate the systems that are causing downtime. 


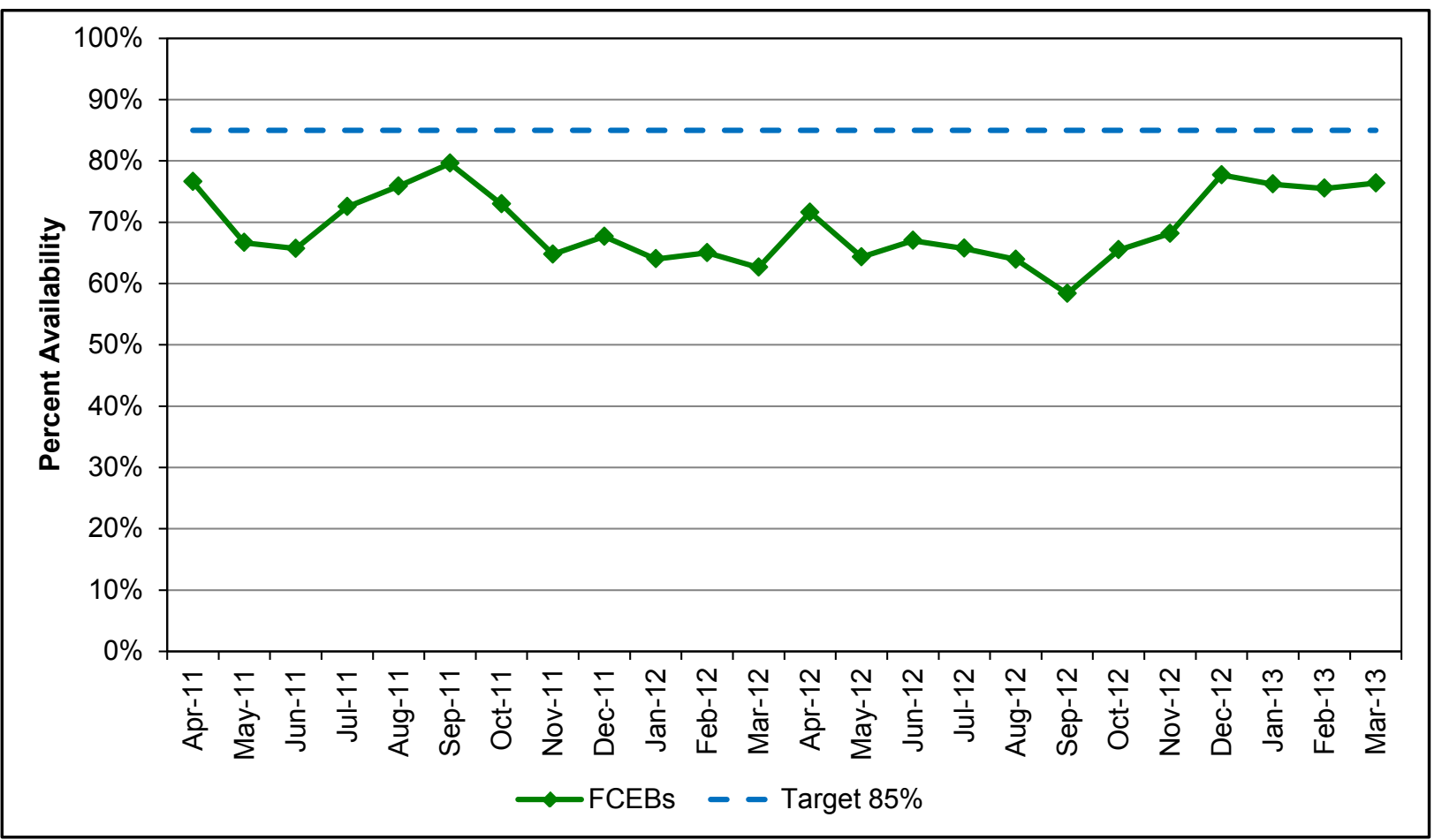

Figure 13. Average monthly availability for the FCEBs

\section{Fuel Consumption, Fuel Economy, and Cost}

$\mathrm{BC}$ Transit provided individual fueling records for all of the buses during the data period. NREL analyzed these records to determine fuel consumption for each bus and the fleet as a whole. BC Transit tracks fuel consumption as kilograms per 100 kilometers $(\mathrm{kg} / 100 \mathrm{~km})$. To compare the FCEB fleet to conventional diesel buses, we also have calculated fuel consumption in liters per 100 kilometers. BC Transit reports that its diesel buses operating in similar service to the FCEBs in Whistler have an average fuel consumption of $55 \mathrm{~L} / 100 \mathrm{~km}$. Table 4 provides the calculated fuel consumption for each bus and the fleet as a whole in both units. For comparison to the FCEBs in the United States, the table also includes fuel economy in miles per kilogram and miles per diesel gallon equivalent. 
Table 4. Fuel Consumption and Fuel Economy (Evaluation Period)

\begin{tabular}{|c|c|c|c|c|}
\hline Bus & $\begin{array}{c}\text { Kilograms } \\
\text { per } 100 \mathrm{~km}\end{array}$ & $\begin{array}{c}\text { Liters per } \\
100 \mathrm{~km}\end{array}$ & $\begin{array}{c}\text { Miles per } \\
\mathrm{kg}\end{array}$ & Miles per DGE \\
\hline 1000 & 16.61 & 55.62 & 3.74 & 4.23 \\
\hline 1001 & 15.62 & 52.31 & 3.98 & 4.50 \\
\hline 1002 & 16.05 & 53.77 & 3.87 & 4.37 \\
\hline 1003 & 15.05 & 50.40 & 4.13 & 4.67 \\
\hline 1004 & 15.16 & 50.78 & 4.10 & 4.63 \\
\hline 1005 & 15.33 & 51.35 & 4.05 & 4.58 \\
\hline 1006 & 16.11 & 53.95 & 3.86 & 4.36 \\
\hline 1007 & 15.28 & 51.18 & 4.07 & 4.60 \\
\hline 1008 & 14.68 & 49.17 & 4.23 & 4.78 \\
\hline 1009 & 15.37 & 51.48 & 4.04 & 4.57 \\
\hline 1010 & 14.98 & 50.19 & 4.15 & 4.69 \\
\hline 1011 & 15.27 & 51.16 & 4.07 & 4.60 \\
\hline 1012 & 15.51 & 51.94 & 4.01 & 4.53 \\
\hline 1013 & 15.46 & 51.78 & 4.02 & 4.54 \\
\hline 1014 & 15.00 & 50.25 & 4.14 & 4.68 \\
\hline 1015 & 15.01 & 50.27 & 4.14 & 4.68 \\
\hline 1016 & 16.24 & 54.40 & 3.83 & 4.32 \\
\hline 1017 & 15.99 & 53.55 & 3.89 & 4.39 \\
\hline 1018 & 16.01 & 53.64 & 3.88 & 4.38 \\
\hline 1019 & 14.95 & 50.07 & 4.16 & 4.70 \\
\hline Total & 15.48 & 52.86 & 4.01 & 4.53 \\
\hline Diesel & & 55.00 & & 4.28 \\
\hline comparison & & & & \\
\hline
\end{tabular}

Figure 14 shows the monthly fuel consumption for the fleet in $\mathrm{kg} / 100 \mathrm{~km}$. Each year of the twoyear data period is presented as a separate line on the chart. The monthly mean ambient temperature for each year is included on the graph to show the seasonal variation. This seasonal variation results in a swing for fuel consumption from a low of around $13 \mathrm{~kg} / 100 \mathrm{~km}$ in the summer months up to a high of $17.8 \mathrm{~kg} / 100 \mathrm{~km}$ during the winter. The average fuel consumption during the entire period is $15.48 \mathrm{~kg} / 100 \mathrm{~km}$. (For a U.S. comparison, the fuel economy varies seasonally from a low of $3.5 \mathrm{mi} / \mathrm{DGE}$ up to $4.9 \mathrm{mi} / \mathrm{DGE}$. The overall fleet average is 4.53 $\mathrm{mi} / \mathrm{DGE}$.) This is higher than the fuel consumption measured for the pilot bus during its 30-day test period. As mentioned previously, the pilot bus was tested primarily in Victoria where the environmental conditions are not as harsh as that of Whistler. Also, the production buses were modified from the original design. Those modifications included the addition of a $20 \mathrm{~kW}$ heater and optimization of the control strategy between the energy storage system and the fuel cell. As a result of these changes, the production buses consume more fuel during operation than the pilot bus did. 


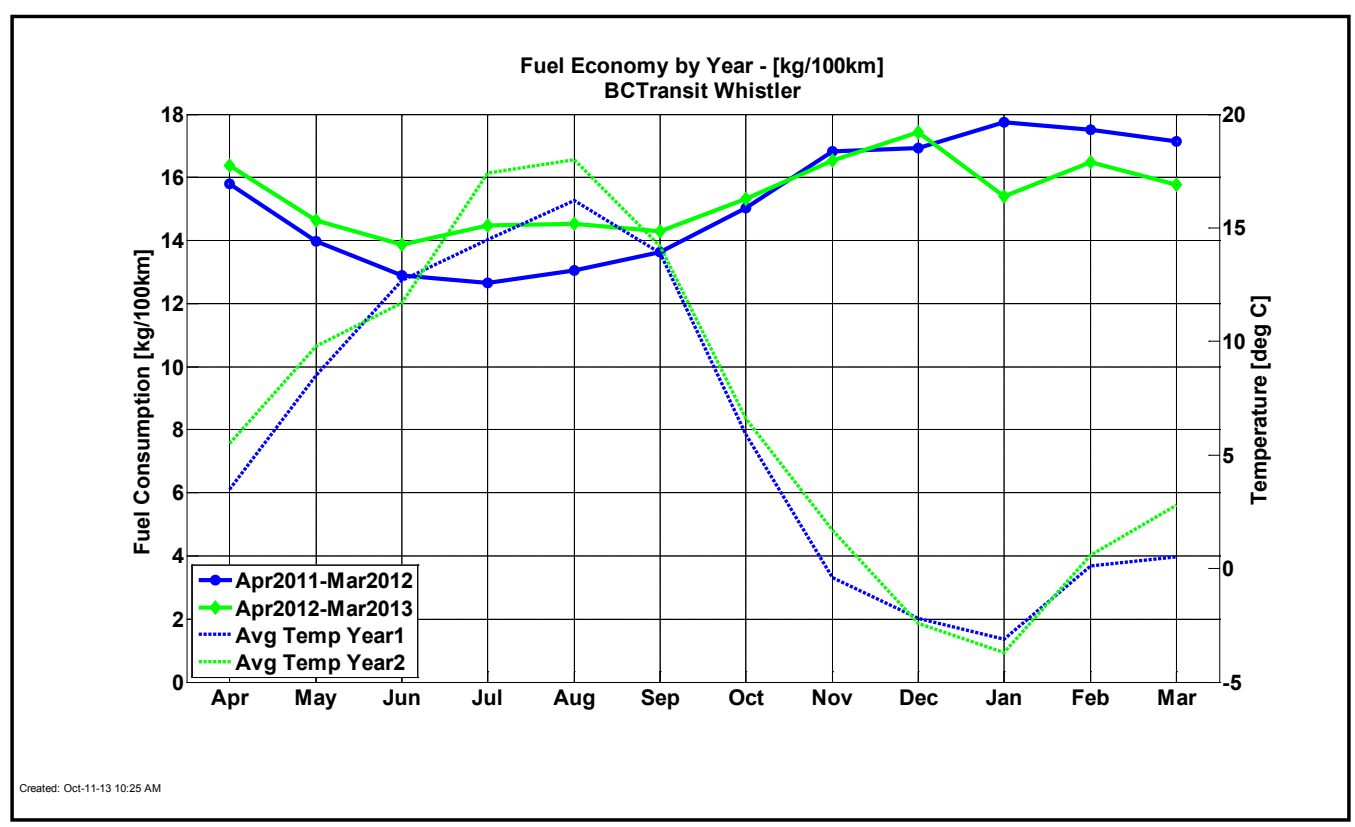

Figure 14. Fuel consumption for the FCEBs in $\mathrm{kg} / 100 \mathrm{~km}$

Figure 15 presents the same information in diesel equivalent $\mathrm{L} / 100 \mathrm{~km}$. For comparison, the average diesel fuel consumption of $55 \mathrm{~L} / 100 \mathrm{~km}$ is included as a black line on the chart. The FCEBs have fuel consumption that is $5 \%$ less than that of the diesel buses. Figure 16 presents the fuel economy in miles per diesel gallon equivalent.

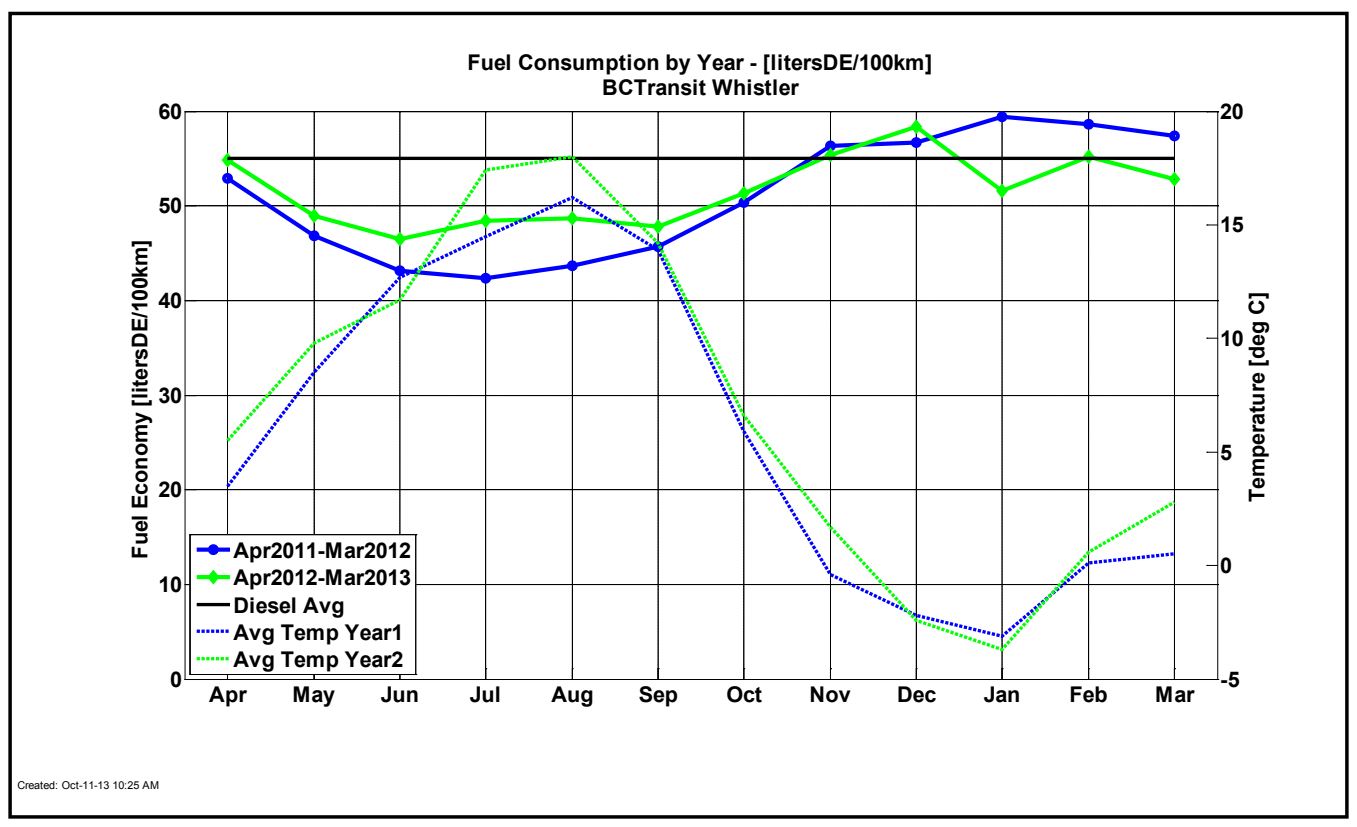

Figure 15. Fuel consumption for the FCEBs in L/100 km 


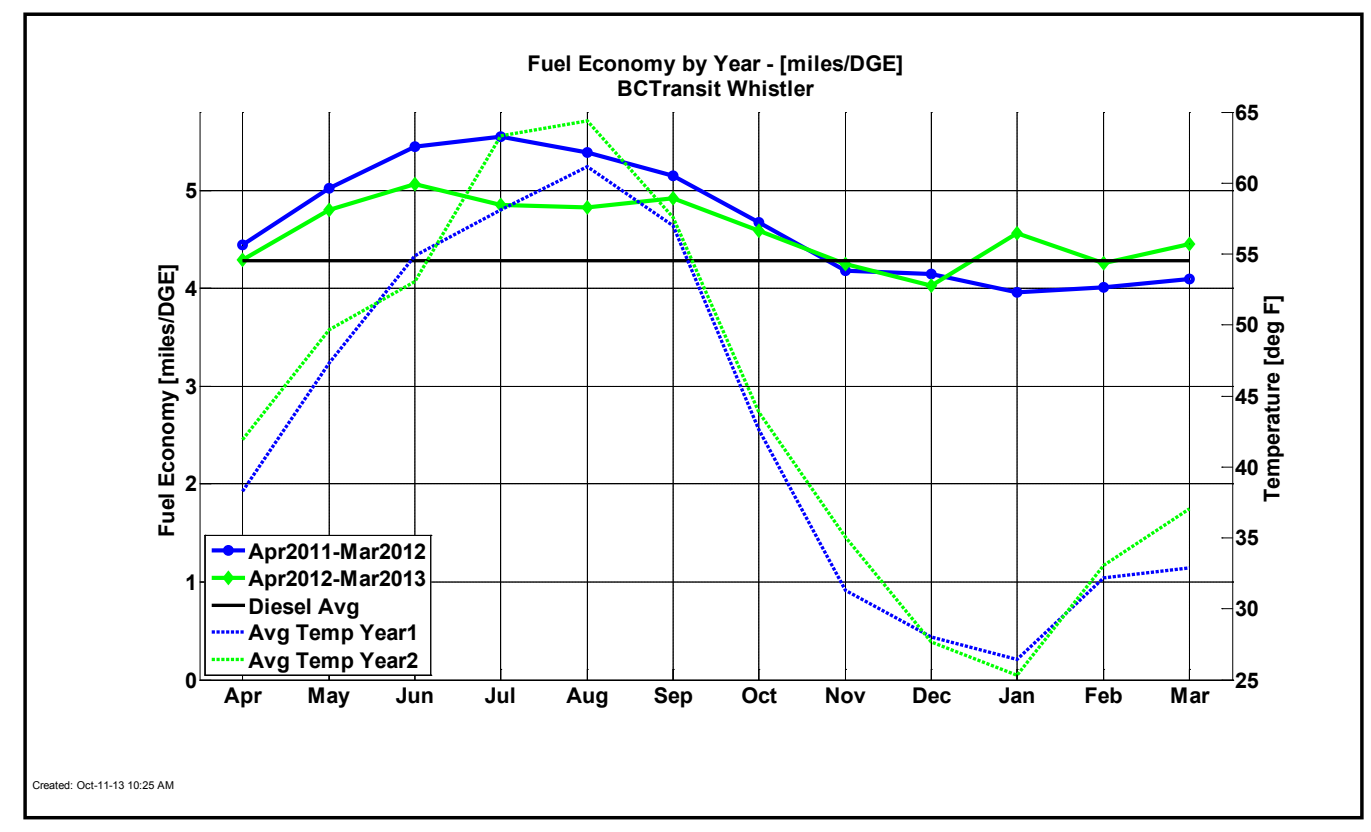

Figure 16. Fuel economy for the FCEBs in mi/DGE

The cost of dispensed hydrogen is $\$ 10.55$ per $\mathrm{kg}$, which excludes any capital or other costs that were paid by BC Transit at the beginning of the project. Based on $\$ 10.55$ per $\mathrm{kg}$, the hydrogen fuel cost per kilometer is $\$ 1.63$ (CAD). This equates to $\$ 2.62$ (USD) per mile.

\section{Maintenance Analysis}

All work orders for the study buses were collected and analyzed for this evaluation. The maintenance labor costs are the actual costs for BC Transit. Labor hours reported are for Whistler Transit staff only - any labor hours by the manufacturers are not captured in the work orders and therefore are not included in the data analysis. It should be emphasized that the FCEBs were under warranty until February 2013 and for the data period presented in the report any high-cost parts are not included in the cost calculations. NREL expects the maintenance costs for materials will increase over the next year as the buses require replacement parts that are no longer covered under warranty. This section first covers total maintenance costs and then maintenance costs by bus system.

\section{Total Maintenance Costs}

Total maintenance costs include the price of parts and labor rates for BC Transit. The labor hours are listed in the tables and can be used by other agencies to estimate the cost for their specific rates. Table 5 shows total maintenance costs for the fuel cell buses in cost per kilometer, $\$ 1.03$, and cost per mile, \$1.60. Scheduled and unscheduled maintenance costs are provided in Table 6. $\mathrm{BC}$ Transit reports that the average maintenance cost for diesel buses in similar service is $\$ 0.65$ per kilometer. Using this for comparison, the FCEBs in this demonstration have a total maintenance cost that is 58\% higher than that of diesel buses. Figure 17 shows the monthly scheduled and unscheduled cost (CAD) per kilometer for the FCEBs during the data period. Figure 19 presents the same data in cost (USD) per mile. 
Table 5. Total Maintenance Costs (Evaluation Period)

\begin{tabular}{|c|c|c|c|c|c|c|}
\hline Bus & Kilometers & Parts $\mathbf{( \$ )}$ & $\begin{array}{c}\text { Labor } \\
\text { Hours }\end{array}$ & $\begin{array}{c}\text { Total Cost } \\
\text { per km (CAD) }\end{array}$ & Miles & $\begin{array}{c}\text { Total Cost per } \\
\text { Mile (USD) }\end{array}$ \\
\hline 1000 & 90,573 & 21231.42 & 1595.4 & 1.23 & 56,279 & 1.92 \\
\hline 1001 & 96,071 & 18965.77 & 1699.7 & 1.20 & 59,696 & 1.86 \\
\hline 1002 & 115,967 & 21783.02 & 1877.78 & 1.06 & 72,059 & 1.65 \\
\hline 1003 & 104,317 & $17,075.46$ & 1761.79 & 1.14 & 64,820 & 1.78 \\
\hline 1004 & 114,544 & $22,838.59$ & 1532.51 & 0.97 & 71,174 & 1.52 \\
\hline 1005 & 110,229 & $30,583.80$ & 1595.79 & 1.06 & 68,493 & 1.65 \\
\hline 1006 & 114,275 & $23,034.99$ & 1615.85 & 1.01 & 71,007 & 1.58 \\
\hline 1007 & 101,651 & $23,203.41$ & 1560.21 & 1.12 & 63,163 & 1.74 \\
\hline 1008 & 101,872 & $18,268.08$ & 1988.25 & 1.13 & 63,300 & 1.75 \\
\hline 1009 & 123,287 & $23,225.64$ & 1603.82 & 0.85 & 76,607 & 1.33 \\
\hline 1010 & 104,027 & $21,724.64$ & 1809.73 & 1.13 & 64,639 & 1.76 \\
\hline 1011 & 110,501 & $14,951.31$ & 1499.87 & 0.89 & 68,662 & 1.38 \\
\hline 1012 & 109,699 & 15617.49 & 1521.35 & 0.88 & 68,164 & 1.36 \\
\hline 1013 & 104,135 & 13424.59 & 1608.3 & 0.93 & 64,706 & 1.44 \\
\hline 1014 & 88,381 & 29504.7 & 1679.14 & 1.39 & 54,917 & 2.16 \\
\hline 1015 & 108,257 & 17914.77 & 1471.75 & 0.93 & 67,268 & 1.44 \\
\hline 1016 & 95,345 & 28767.28 & 1701.54 & 1.25 & 59,245 & 1.94 \\
\hline 1017 & 109,466 & 14878.85 & 1314.32 & 0.83 & 68,019 & 1.30 \\
\hline 1018 & 110,467 & 17866.44 & 1606.3 & 0.90 & 68,641 & 1.41 \\
\hline 1019 & 109,387 & 12146.07 & 1377.98 & 0.81 & 67,970 & 1.25 \\
\hline Total & $\mathbf{2 , 1 2 2 , 4 5 1}$ & $\mathbf{4 0 7 , 0 0 6}$ & $\mathbf{3 2 , 4 2 1}$ & $\mathbf{1 . 0 3}$ & $\mathbf{1 , 3 1 8 , 8 3 0}$ & $\mathbf{1 . 6 0}$ \\
\hline
\end{tabular}

Table 6. Scheduled and Unscheduled Maintenance Costs (Evaluation Period)

\begin{tabular}{|c|c|c|c|c|c|c|}
\hline Bus & Kilometers & $\begin{array}{c}\text { Scheduled } \\
\text { Cost per km } \\
\text { (CAD) }\end{array}$ & $\begin{array}{c}\text { Unscheduled } \\
\text { Cost per km } \\
\text { (CAD) }\end{array}$ & Miles & $\begin{array}{c}\text { Scheduled } \\
\text { Cost per } \\
\text { Mile (USD) }\end{array}$ & $\begin{array}{c}\text { Unscheduled } \\
\text { Cost per Mile } \\
\text { (USD) }\end{array}$ \\
\hline 1000 & 90,573 & 0.22 & 1.02 & 56,279 & 0.34 & 1.58 \\
\hline 1001 & 96,071 & 0.24 & 0.95 & 59,696 & 0.38 & 1.48 \\
\hline 1002 & 115,967 & 0.21 & 0.85 & 72,059 & 0.33 & 1.32 \\
\hline 1003 & 104,317 & 0.21 & 0.93 & 64,820 & 0.33 & 1.44 \\
\hline 1004 & 114,544 & 0.24 & 0.74 & 71,174 & 0.37 & 1.14 \\
\hline 1005 & 110,229 & 0.19 & 0.87 & 68,493 & 0.30 & 1.35 \\
\hline 1006 & 114,275 & 0.21 & 0.81 & 71,007 & 0.32 & 1.26 \\
\hline 1007 & 101,651 & 0.23 & 0.88 & 63,163 & 0.37 & 1.38 \\
\hline 1008 & 101,872 & 0.20 & 0.93 & 63,300 & 0.31 & 1.44 \\
\hline 1009 & 123,287 & 0.18 & 0.67 & 76,607 & 0.29 & 1.04 \\
\hline 1010 & 104,027 & 0.19 & 0.95 & 64,639 & 0.29 & 1.47 \\
\hline 1011 & 110,501 & 0.18 & 0.70 & 68,662 & 0.29 & 1.09 \\
\hline 1012 & 109,699 & 0.19 & 0.68 & 68,164 & 0.30 & 1.06 \\
\hline 1013 & 104,135 & 0.19 & 0.73 & 64,706 & 0.30 & 1.14 \\
\hline 1014 & 88,381 & 0.21 & 1.18 & 54,917 & 0.32 & 1.84 \\
\hline 1015 & 108,257 & 0.21 & 0.72 & 67,268 & 0.33 & 1.12 \\
\hline 1016 & 95,345 & 0.20 & 1.05 & 59,245 & 0.31 & 1.63 \\
\hline 1017 & 109,466 & 0.21 & 0.62 & 68,019 & 0.33 & 0.96 \\
\hline 1018 & 110,467 & 0.19 & 0.71 & 68,641 & 0.30 & 1.11 \\
\hline 1019 & 109,387 & 0.22 & 0.59 & 67,970 & 0.34 & 0.91 \\
\hline Total & $\mathbf{2 , 1 2 2 , 4 5 1}$ & $\mathbf{0 . 2 1}$ & $\mathbf{0 . 8 2}$ & $\mathbf{1 , 3 1 8 , 8 3 0}$ & $\mathbf{0 . 3 2}$ & $\mathbf{1 . 2 7}$ \\
\hline
\end{tabular}




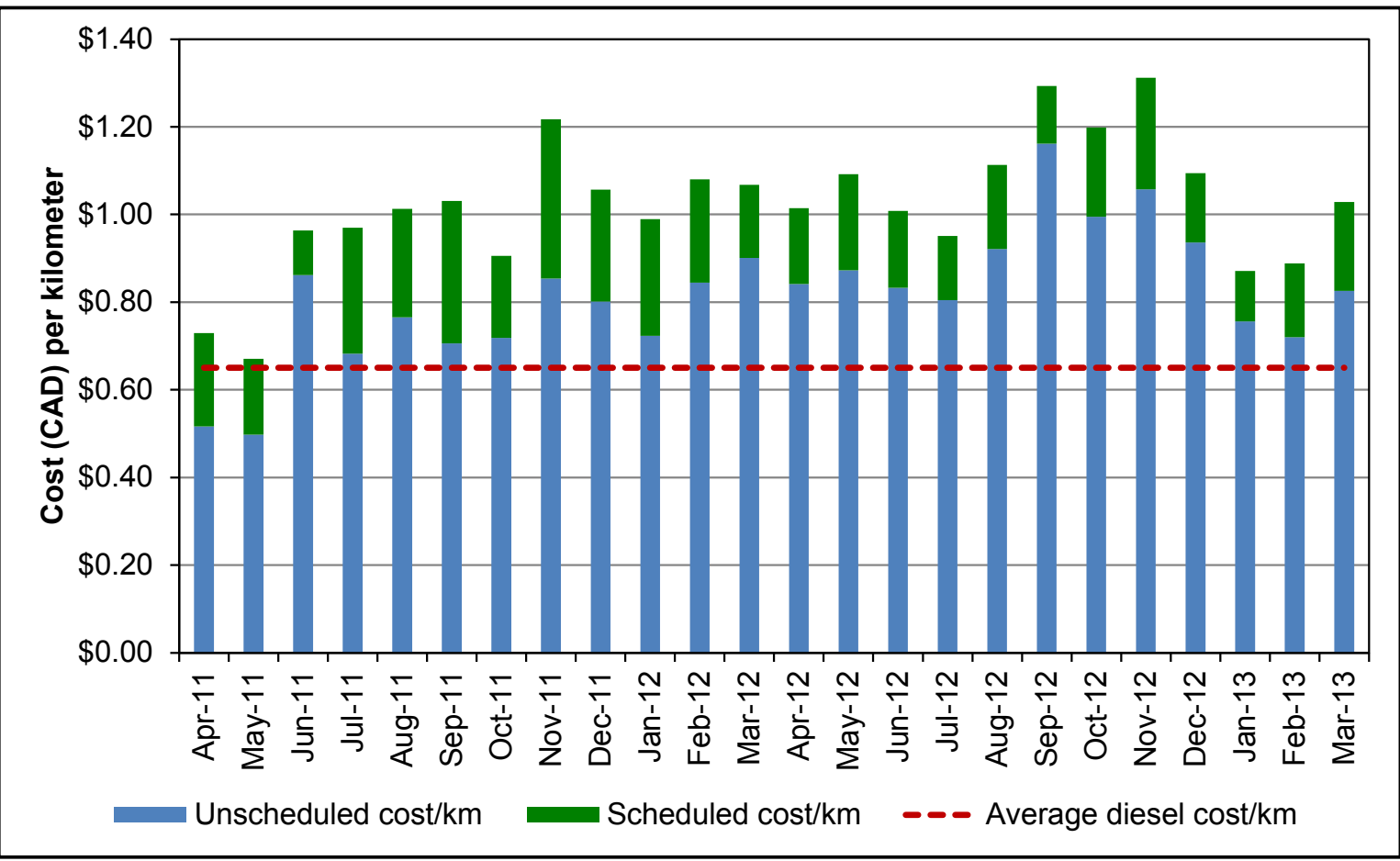

Figure 17. Monthly scheduled and unscheduled costs (CAD) per kilometer for the FCEBs

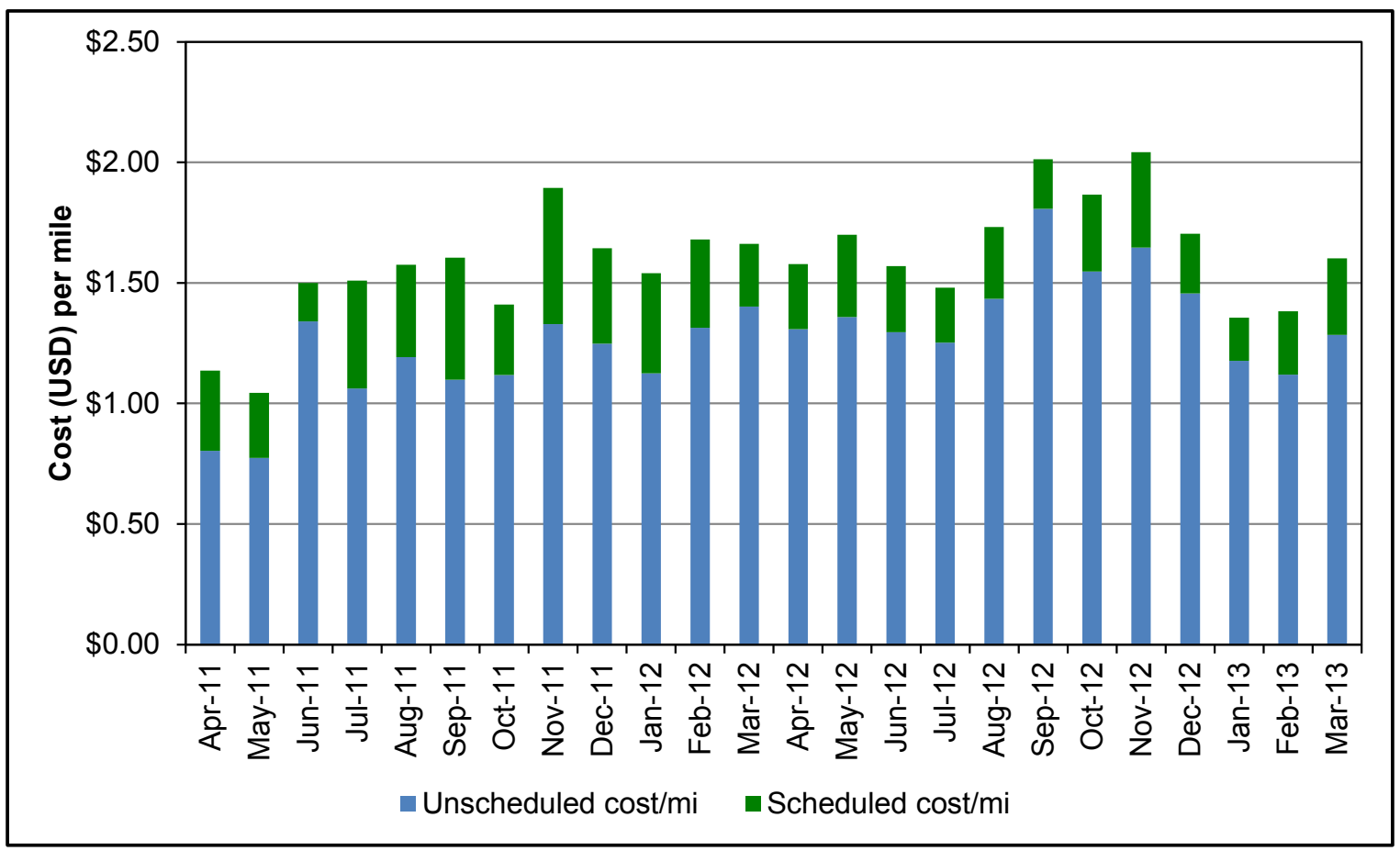

Figure 18. Monthly scheduled and unscheduled costs (USD) per mile for the FCEBs 


\section{Maintenance Costs Categorized by System}

Table 8 shows maintenance costs itemized by vehicle system (without warranty costs). The vehicle systems shown in the table are as follows:

- Cab, body, and accessories - Includes body, glass, and paint repairs following accidents; cab and sheet metal repairs on seats and doors; and accessory repairs such as hubodometers and radios

- Propulsion-related systems - Repairs for exhaust, fuel, engine, electric motors, fuel cell modules, propulsion control, non-lighting electrical (charging, cranking, and ignition), air intake, cooling, and transmission

- Preventive maintenance inspections (PMI) - Labor for inspections during preventive maintenance

- Brakes

- Frame, steering, and suspension

- Heating, ventilation, and air conditioning (HVAC)

- Lighting

- Air system, general

- Axles, wheels, and drive shaft

- Tires.

Table 7. Maintenance Cost by System (Evaluation Period)

\begin{tabular}{|l|c|c|c|}
\hline \multicolumn{1}{|c|}{ System } & $\begin{array}{c}\text { Cost per } \\
\text { Kilometer (CAD) }\end{array}$ & $\begin{array}{c}\text { Cost per } \\
\text { Mile (USD) }\end{array}$ & $\begin{array}{c}\text { Percent of } \\
\text { Total (\%) }\end{array}$ \\
\hline Cab, body, and accessories & 0.12 & 0.19 & 12.2 \\
\hline Propulsion-related & 0.59 & 0.91 & 57.3 \\
\hline PMI & 0.13 & 0.20 & 12.4 \\
\hline Brakes & 0.03 & 0.05 & 3.4 \\
\hline Frame, steering, and suspension & 0.05 & 0.07 & 4.5 \\
\hline HVAC & 0.04 & 0.06 & 3.7 \\
\hline Lighting & 0.02 & 0.03 & 1.6 \\
\hline Air, general & 0.00 & 0.00 & 0.2 \\
\hline Axles, wheels, and drive shaft & 0.02 & 0.03 & 2.1 \\
\hline Tires & 0.03 & 0.04 & 2.6 \\
\hline Total & $\mathbf{1 . 0 3}$ & $\mathbf{1 . 6 0}$ & $\mathbf{1 0 0}$ \\
\hline
\end{tabular}

The propulsion system had the highest percentage of maintenance costs for the FCEBs at more than $57 \%$ of the total costs. The categories of PMI and cab, body, and accessories had approximately the same percentage of maintenance costs at $12 \%$. Figure 19 charts the monthly labor hours by system and clearly shows that throughout the data period the majority of labor was for the propulsion system. 


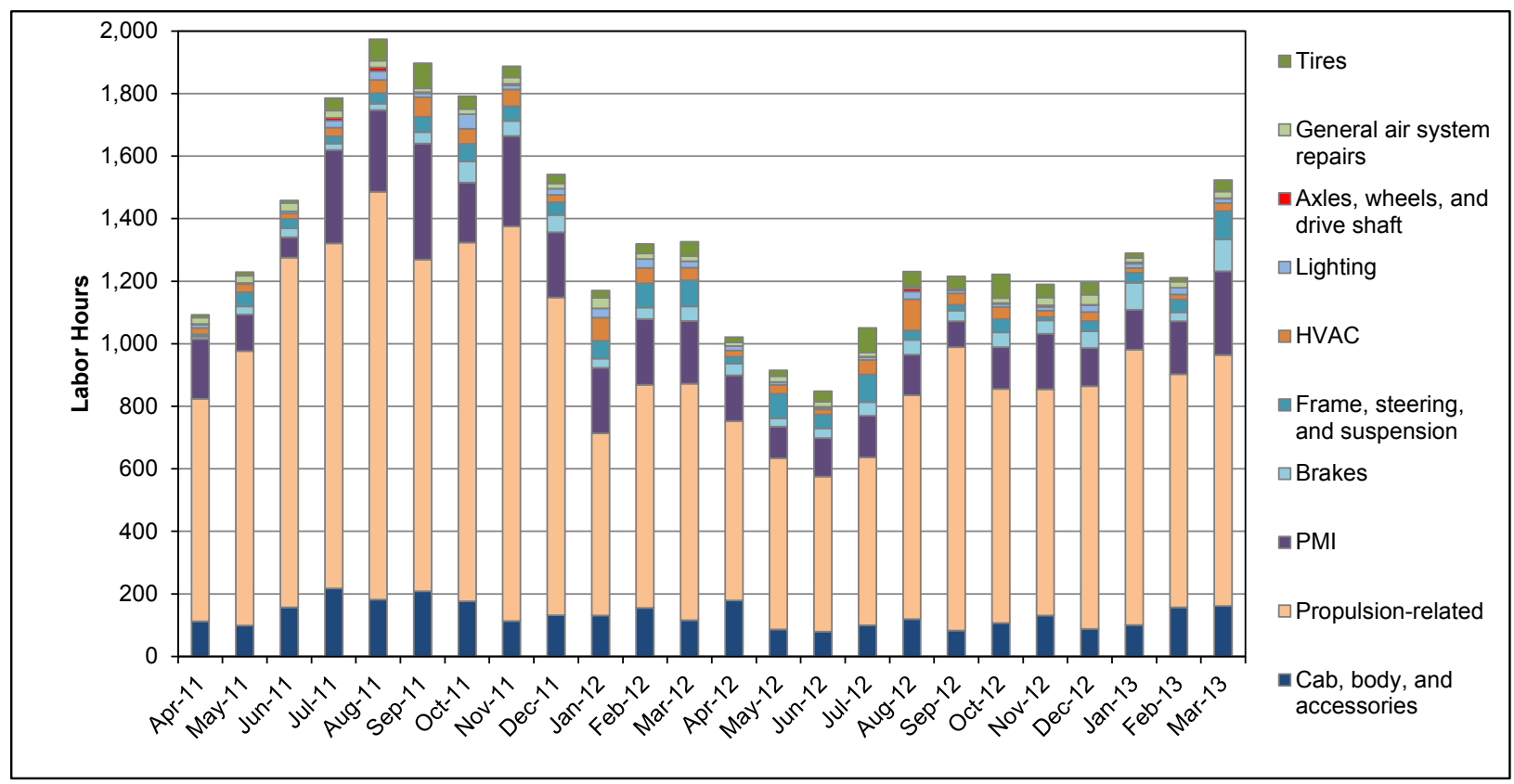

Figure 19. Monthly labor hours by maintenance category

\section{Propulsion-Related Maintenance Costs}

Propulsion-related vehicle systems include the exhaust, fuel, power plant, electric propulsion system components, air intake, cooling, non-lighting electrical, and transmission systems. These systems have been separated to highlight the maintenance costs most directly affected by the advanced propulsion system changes for the buses.

Table 9 shows the propulsion-related system repairs by category for the FCEBs during the reporting period in CAD per kilometer and USD per mile. The first section of the table shows the total for all categories within the propulsion system. The cooling system and compressor are part of the fuel cell balance of plant but have been separated out in the table. The labor costs for the Brusa charging have also been separated out to give an indication of the added time needed for this activity. The three categories with the highest repair cost were electric motor and propulsion repairs; power plant system repairs; and cooling system repairs. Figure 20 shows the monthly labor costs for the propulsion system by category.

As mentioned previously, the FCEBs have been under warranty for the data period in the report. This will change over the next year as the buses reach the end of the warranty period, and maintenance costs are expected to rise once this happens. NREL will document these costs in the next report. 
Table 8. Propulsion-Related Maintenance Costs by System (Evaluation Period)

\begin{tabular}{|l|r|r|}
\hline Maintenance System Costs & Kilometers / CAD & Miles / USD \\
\hline Distance traveled & $2,122,451$ & $1,318,830$ \\
\hline Total Propulsion-Related Systems (Roll-up) \\
\hline Parts cost (\$) & $226,601.07$ & $219,123.23$ \\
\hline Labor hours & $20,105.3$ & $20,105.3$ \\
\hline Total cost (\$) & $1,244,825.20$ & $1,203,745.96$ \\
\hline Total cost (\$) per mile & 0.59 \\
\hline Fuel System Repairs & $33,504.41$ & 0.91 \\
\hline Parts cost (\$) & $1,482.3$ & $32,398.77$ \\
\hline Labor hours & $111,088.17$ & $107,482.3$ \\
\hline Total cost (\$) & 0.05 & 0.08 \\
\hline Total cost (\$) per mile & $19,488.65$ & $18,845.53$ \\
\hline Power Plant System Repairs & $4,804.1$ & $4,804.1$ \\
\hline Parts cost (\$) & $276,065.65$ & $266,955.49$ \\
\hline Labor hours & 0.13 \\
\hline Total cost (\$) & \multicolumn{3}{|c|}{0.20} \\
\hline Total cost (\$) per mile & $26,828.83$ & $25,943.48$ \\
\hline Electric Motor and Propulsion Repairs & $5,899.6$ & $5,899.6$ \\
\hline Parts cost (\$) & $301,304.67$ & $291,361.62$ \\
\hline Labor hours & 0.14 & 0.22 \\
\hline Total cost (\$) & 317.61 & 307.13 \\
\hline Total cost (\$) per mile & 953.2 & 953.2 \\
\hline Compressor Repairs & $45,210.79$ & $43,718.83$ \\
\hline Parts cost (\$) & 0.02 & 0.03 \\
\hline Labor hours &
\end{tabular}

\begin{tabular}{|c|c|c|}
\hline \multicolumn{3}{|c|}{$\begin{array}{l}\text { Non-Lighting Electrical System Repairs (General Electrical, } \\
\text { Charging, Cranking, Ignition) }\end{array}$} \\
\hline Parts cost $(\$)$ & $46,496.78$ & $44,962.39$ \\
\hline Labor hours & $2,210.3$ & $2,210.3$ \\
\hline Total cost $(\$)$ & $142,482.80$ & $137,780.87$ \\
\hline Total cost $(\$)$ per mile & 0.07 & 0.10 \\
\hline \multicolumn{3}{|c|}{ Air Intake System Repairs } \\
\hline Parts cost $(\$)$ & $40,740.39$ & $39,395.96$ \\
\hline Labor hours & 22.7 & 22.7 \\
\hline Total cost $(\$)$ & $42,062.34$ & $40,674.28$ \\
\hline Total cost $(\$)$ per mile & 0.02 & 0.03 \\
\hline \multicolumn{3}{|c|}{ Cooling System Repairs } \\
\hline Parts cost $(\$)$ & $59,224.39$ & $57,269.98$ \\
\hline Labor hours & $2,699.7$ & $2,699.7$ \\
\hline Total cost $(\$)$ & $210,038.54$ & $203,107.27$ \\
\hline Total cost (\$) per mile & 0.10 & 0.15 \\
\hline \multicolumn{3}{|l|}{ Brusa Charging } \\
\hline Parts cost $(\$)$ & 0.00 & 0.00 \\
\hline Labor hours & $2,033.4$ & $2,033.4$ \\
\hline Total cost $(\$)$ & $116,572.23$ & $112,725.35$ \\
\hline Total cost (\$) per mile & 0.05 & 0.09 \\
\hline
\end{tabular}




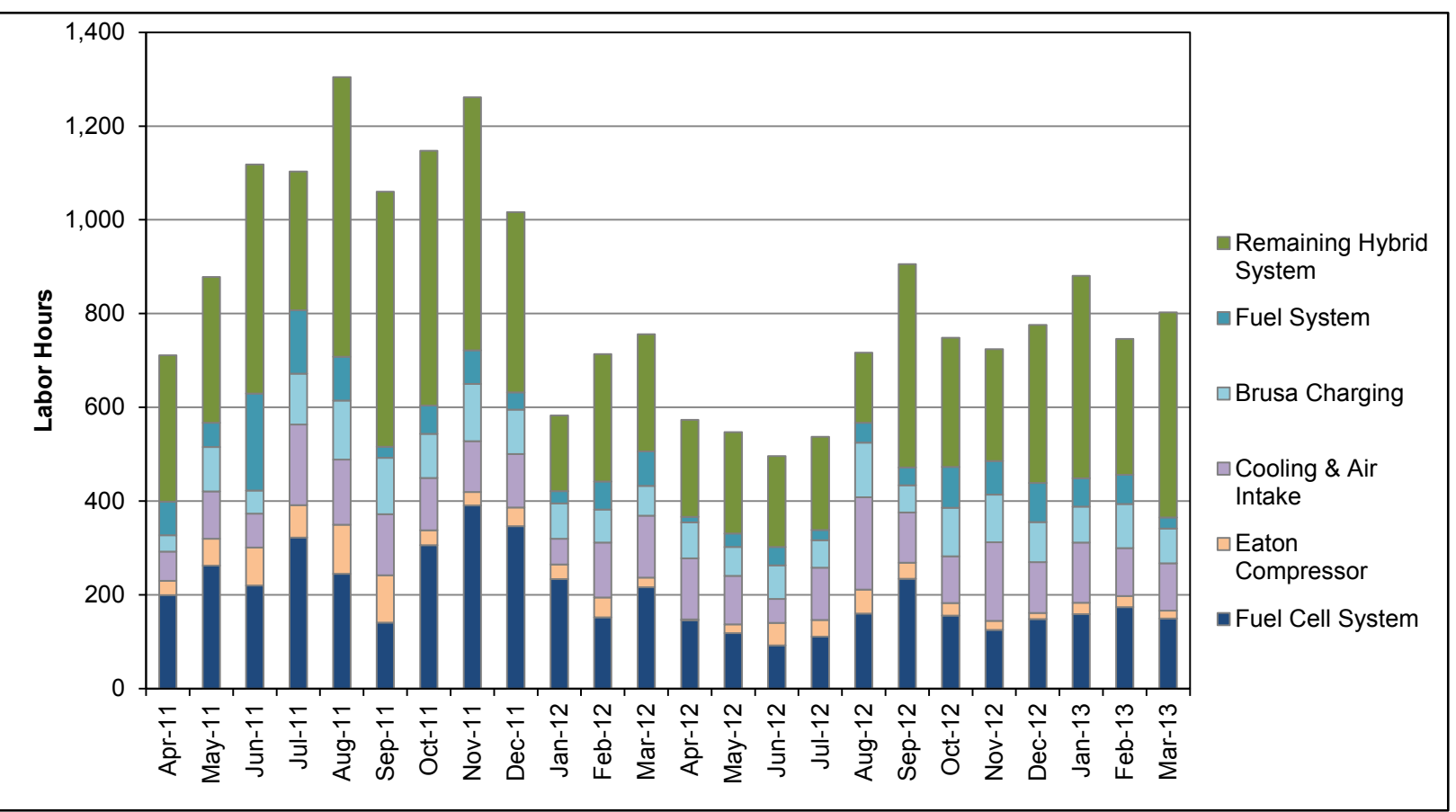

Figure 20. Monthly propulsion-related labor hours by category 


\section{Roadcall Analysis}

A roadcall or revenue vehicle system failure (as named in the National Transit Database ${ }^{12}$ ) is defined as a failure of an in-service bus that causes the bus to be replaced on route or causes a significant delay in schedule. If the problem with the bus can be repaired during a layover and the schedule is kept, this is not considered a roadcall. The analysis described here includes only roadcalls that were caused by "chargeable" failures. Chargeable roadcalls include systems that can physically disable the bus from operating on route, such as interlocks (doors, air system), engine, or things that are deemed to be safety issues if operation of the bus continues. They do not include roadcalls for things such as problems with radios or destination signs.

Table 10 shows the mean distance between roadcall for the FCEBs categorized by total bus roadcalls, propulsion-related roadcalls, and fuel-cell-related roadcalls. The results are presented in kilometers as well as miles. Figure 21 presents these data graphically, charting the cumulative mean distance between roadcall for each category. BC Transit's target of 5,000 kilometers between roadcall is included in the chart (orange dashed line). In the United States, DOE and FTA have set targets for miles between roadcall (MBRC) for FCEBs. These are also included on the graph for comparison.

Table 9. Roadcalls and Mean Distance Between Roadcall (Evaluation Period)

\begin{tabular}{|l|c|c|}
\hline & Kilometers & Miles \\
\hline Mileage & $2,122,451$ & $1,318,830$ \\
\hline All roadcalls & 866 & 866 \\
\hline Bus mean distance between roadcall & 2,451 & 1,523 \\
\hline Propulsion-related roadcalls & 655 & 655 \\
\hline Propulsion mean distance between roadcall & 3,240 & 2,013 \\
\hline Fuel-cell-related roadcalls & 158 & 158 \\
\hline Fuel cell system mean distance between roadcall & 13,433 & 8,347 \\
\hline
\end{tabular}

\footnotetext{
${ }^{12}$ National Transit Database website: www.ntdprogram.gov/ntdprogram/.
} 


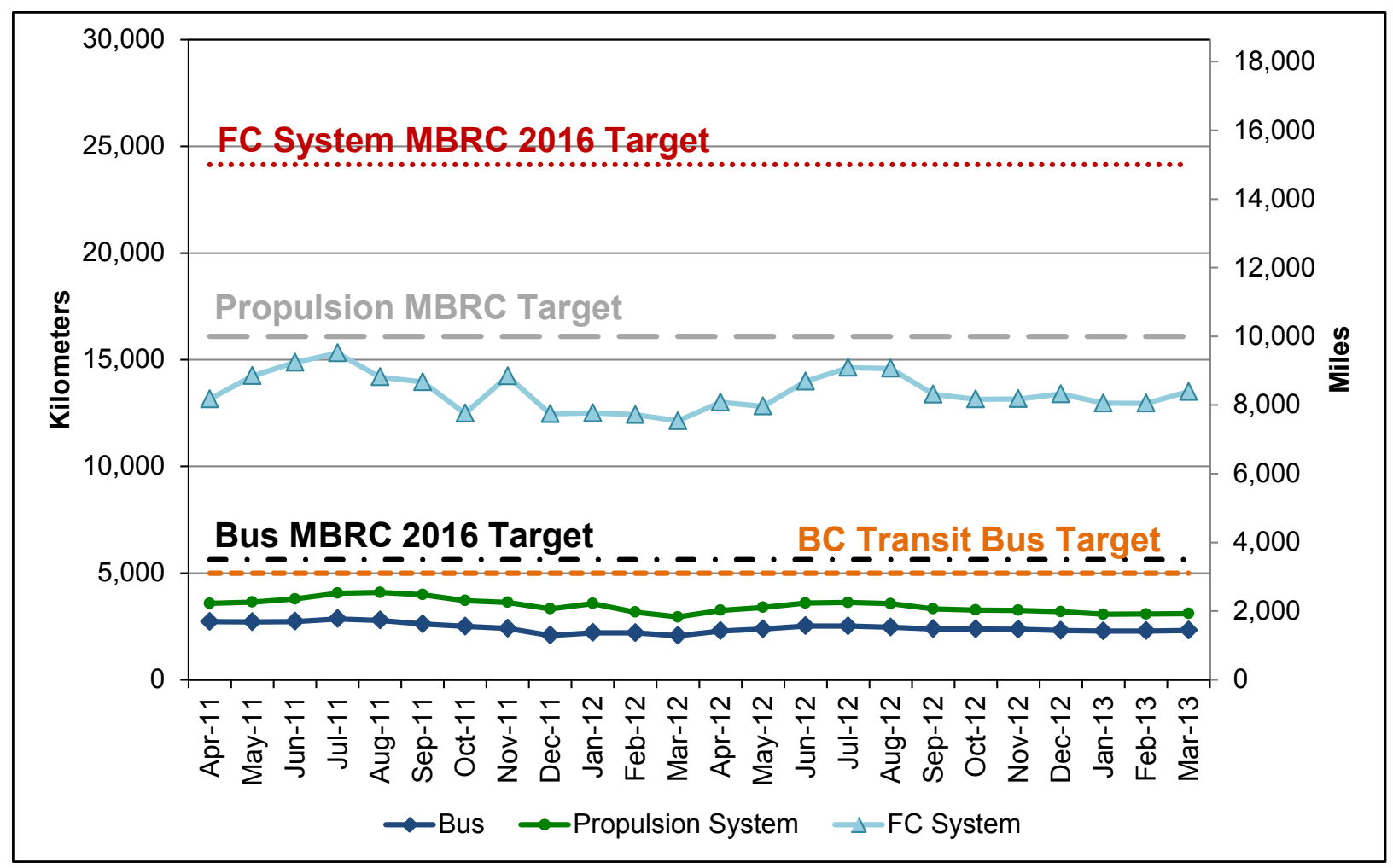

Figure 21. Cumulative distance between roadcall for the FCEBs 


\section{What's Next for BC Transit}

BC Transit will continue to operate the FCEBs through the end of the planned demonstration period, which ends March 2014. After four years, this fleet remains the largest FCEB fleet in operation at a single location, making the demonstration a significant accomplishment in the development of the technology. The agency will be reviewing the final performance results and evaluating options for the buses over the next few months.

From BC Transit's perspective, FCEB development must address the following to make the technology feasible for transit operation:

- Improve the reliability of systems and components

- Lower the purchase and operational cost to levels approaching that of current technology

- $\quad$ Reduce the maintenance cost

- Establish a sustainable parts supply chain

- Lower the fuel consumption and the cost of hydrogen

- Further reduce bus weight

- Improve fueling times

- Define the necessary requirements for hydrogen stations to service larger fleets

- Improve diagnostics systems.

NREL will continue to evaluate the buses and will collect data through the demonstration period. A second report outlining the final performance results is expected to be published in summer 2014. 


\section{Contacts}

NREL

15013 Denver West Parkway

Golden, CO 80401

Leslie Eudy, Senior Project Leader

Phone: 303-275-4412

Email: leslie.eudy@nrel.gov

\section{California Air Resources Board}

1001 I Street

Sacramento, CA 95812

Lesley Stern, Air Resources Engineer

Sustainable Transportation Technologies Branch, Mobile Source Control Division

Phone: 916-323-2913

Email:1stern@arb.ca.gov

BC Transit

520 Gorge Road East

Victoria, BC, Canada V8W 2P3

Mike Frost, Director, Fleet Asset Management

Phone: 250-995-5722

Ballard Power Systems

9000 Glenlyon Parkway

Burnaby, BC, Canada

Jeff Grant, Commercial Lead, North American Bus Market

Phone: 604-315-3578

Email: jeff.grant@ballard.com

New Flyer

711 Kernagham Avenue

Winnipeg, Manitoba, Canada R2C 3T4

Chris Stoddart, VP Engineering Services

Phone: 204-224-1251 


\section{References and Related Reports}

All NREL hydrogen and fuel cell-related evaluation reports can be downloaded from the following website: www.nrel.gov/hydrogen/proj_fc_bus_eval.html.

\section{AC Transit}

Chandler, K.; Eudy, L. (2012). Zero Emission Bay Area (ZEBA) Fuel Cell Bus Demonstration: Second Results Report. NREL/TP-5600-55367. Golden, CO: National Renewable Energy Laboratory.

Chandler, K.; Eudy, L. (2011). Zero Emission Bay Area (ZEBA) Fuel Cell Bus Demonstration: First Results Report. NREL/TP-5600-52015. Golden, CO: National Renewable Energy Laboratory.

Eudy, L. (2010). Bay Area Transit Agencies Propel Fuel Cell Buses Toward Commercialization. DOE/GO-102010-3067. Golden, CO: National Renewable Energy Laboratory.

Chandler, K.; Eudy, L. (2010). National Fuel Cell Bus Program: Accelerated Testing Evaluation Report \#2 and Appendices. FTA-CO-26-7004-2010.1. Golden, CO: National Renewable Energy Laboratory.

Chandler, K.; Eudy, L. (2009). National Fuel Cell Bus Program: Accelerated Testing Evaluation Report and Appendices. FTA-CO-26-7004-2009.1. Golden, CO: National Renewable Energy Laboratory.

\section{General}

Eudy, L.; Chandler, K.; Gikakis, C. (2012). Fuel Cell Buses in U.S. Transit Fleets: Current Status 2012. NREL/TP-5600-56406. Golden, CO: National Renewable Energy Laboratory.

Chandler, K.; Eudy, L. (2012). FTA Fuel Cell Bus Program: Research Accomplishments through 2011. FTA Report No. 0014. Washington, DC: Federal Transit Administration.

Eudy, L.; Chandler, K.; Gikakis, C. (2011). Fuel Cell Buses in U.S. Transit Fleets: Current Status 2011. NREL/TP-5600-52927. Golden, CO: National Renewable Energy Laboratory.

Eudy, L. (2010). Fuel Cell Transit Bus Evaluations, Joint Evaluation Plan for the U.S.

Department of Energy and the Federal Transit Administration. NREL/TP-560-49342. Golden, CO: National Renewable Energy Laboratory.

\section{BurbankBus}

Eudy, L. (2010). Fuel Cell Bus Takes a Starring Role in the BurbankBus Fleet. DOE/GO102010-3035. Golden, CO: National Renewable Energy Laboratory.

\section{Connecticut Transit}

Eudy, L. (2011). Connecticut Nutmeg Fuel Cell Bus Project: Demonstrating Advanced-Design Hybrid Fuel Cell Buses in Connecticut. DOT/FTA - NFCBP - FC3 - July 2011. 
Chandler, K.; Eudy, L. (2010) Connecticut Transit (CTTRANSIT) Fuel Cell Transit Bus: Third Evaluation Report and Appendices. NREL/TP-560-47334-1, NREL/TP-560-47334-2. Golden, CO: National Renewable Energy Laboratory.

\section{San Francisco Municipal Transportation Agency}

Eudy, L. (2011). Compound Fuel Cell Hybrid Bus Hits the Streets of San Francisco: San

Francisco Hosts National Fuel Cell Bus Program Demonstration. DOT/FTA - NFCBP - FC2 July 2011.

\section{SunLine}

Eudy, L.; Chandler, K. (2013). SunLine Transit Agency Advanced Technology Fuel Cell Bus Evaluation: Forth Results Report. NREL/TP-5600-57560. Golden, CO: National Renewable Energy Laboratory.

Eudy, L.; Chandler, K. (2012). SunLine Transit Agency Advanced Technology Fuel Cell Bus Evaluation: Third Results Report. NREL/TP-5600-54427. Golden, CO: National Renewable Energy Laboratory.

Eudy, L. (2012). American Fuel Cell Bus Project: Developing and Demonstrating the NextGeneration Fuel Cell Electric Bus Made in America. DOT/FTA - NFCBP - FC4 - March 2012.

Eudy, L.; Chandler, K. (2011). SunLine Transit Agency Advanced Technology Fuel Cell Bus Evaluation: Second Results Report and Appendices. NREL/TP-5600-52349-1, NREL/TP-560052349-2. Golden, CO: National Renewable Energy Laboratory.

Eudy, L.; Chandler, K. (2011). SunLine Transit Agency, Advanced Technology Fuel Cell Bus Evaluation: First Results Report. NREL/TP-5600-50500. Golden, CO: National Renewable Energy Laboratory.

Eudy, L.; Chandler, K. (2009). SunLine Transit Agency, Fuel Cell Transit Bus: Fifth Evaluation Report and Appendices. NREL/TP-560-46346-1, NREL/TP-560-46346-2. Golden, CO: National Renewable Energy Laboratory. 


\section{Appendix A: Fleet Summary Statistics—SI Units \\ Fleet Summary Statistics: BC Transit FCEB \\ Fleet Operations and Economics}

\begin{tabular}{|l|r|r|r|}
\hline & FCEB Year 1 & FCEB Year 2 & FCEB Total \\
\hline Number of vehicles & 20 & 20 & 20 \\
\hline Period used for fuel and oil op analysis & $4 / 11-3 / 12$ & $4 / 12-3 / 13$ & $4 / 11-3 / 13$ \\
\hline Total number of months in period & 12 & 12 & 24 \\
\hline Fuel and oil analysis base fleet kilometers & 962,253 & $1,097,634$ & $2,059,887$ \\
\hline Period used for maintenance op analysis & $4 / 11-3 / 12$ & $4 / 12-3 / 13$ & $4 / 11-3 / 13$ \\
\hline Total number of months in period & 12 & 12 & 24 \\
\hline Maintenance analysis base fleet kilometers & $1,024,047$ & $1,098,404$ & $2,122,451$ \\
\hline Average monthly kilometers per vehicle & 4,267 & 4,577 & 4,422 \\
\hline Availability & $69 \%$ & $69 \%$ & $69 \%$ \\
\hline Fleet fuel usage (H in kg/ diesel in $_{\text {gallons) }}$ & $148,707.10$ & $170,236.70$ & $318,943.70$ \\
\hline Roadcalls & 412 & 454 & 866 \\
\hline RCs KBRC & 2,486 & 2,419 & 2,451 \\
\hline Propulsion roadcalls & 308 & 347 & 655 \\
\hline Propulsion KBRC & 3,325 & 3,165 & 3,240 \\
\hline Fleet kg hydrogen/100 km (1.13 kg H $\left.{ }_{2}\right)$ & 15.45 & 15.51 & 15.48 \\
\hline Rep. fleet fuel consumption (L/100 km) & 51.76 & 51.95 & 51.86 \\
\hline Hydrogen cost per kg & 10.55 & 10.55 & 10.55 \\
\hline Fuel cost per kilometer & $\mathbf{1 . 6 3}$ & $\mathbf{1 . 6 4}$ & $\mathbf{1 . 6 3}$ \\
\hline Total scheduled repair cost per kilometer & 0.24 & 0.18 & 0.21 \\
\hline Total unscheduled repair cost per kilometer & 0.75 & 0.88 & 0.82 \\
\hline Total maintenance cost per kilometer & $\mathbf{0 . 9 9}$ & $\mathbf{1 . 0 6}$ & $\mathbf{1 . 0 3}$ \\
\hline Total operating cost per kilometer & $\mathbf{2 . 6 2}$ & $\mathbf{2 . 6 9}$ & $\mathbf{2 . 6 6}$ \\
\hline
\end{tabular}

\section{Maintenance Costs}

\begin{tabular}{|l|r|r|r|}
\hline & FCEB Year 1 & FCEB Year 2 & FCEB Total \\
\hline Fleet mileage & $1,024,047$ & $1,098,404$ & $2,122,451$ \\
\hline Total parts cost & $157,442.68$ & $249,563.62$ & $407,006.30$ \\
\hline Total labor hours & $18,473.12$ & $13,914.48$ & $32,387.60$ \\
\hline Labor cost & $855,066.48$ & $912,893.22$ & $1,767,959.70$ \\
\hline Total maintenance cost & $1,012,509.16$ & $1,162,456.84$ & $2,174,966.00$ \\
\hline Total maintenance cost per bus & $50,625.46$ & $58,122.84$ & $108,748.30$ \\
\hline Total maintenance cost per kilometer & $\mathbf{0 . 9 9}$ & $\mathbf{1 . 0 6}$ & $\mathbf{1 . 0 2}$ \\
\hline
\end{tabular}




\section{Breakdown of Maintenance Costs by Vehicle System}

\begin{tabular}{|c|c|c|c|}
\hline & FCEB Year 1 & FCEB Year 2 & FCEB Total \\
\hline Fleet mileage & $1,024,047$ & $1,098,404$ & $2,122,451$ \\
\hline \multicolumn{4}{|c|}{ Total Engine/Fuel-Related Systems (ATA VMRS 27, 30, 31, 32, 33, 41, 42, 43, 44, 45, 46, 65) } \\
\hline Parts cost & $91,796.03$ & $134,805.04$ & $226,601.07$ \\
\hline Labor hours & $11,651.96$ & $8,453.33$ & $20,105.29$ \\
\hline Labor cost & $464,516.82$ & $553,707.31$ & $1,018,224.13$ \\
\hline Total cost (for system) & $556,312.85$ & $688,512.35$ & $1,244,825.20$ \\
\hline Total cost (for system) per bus & $27,815.64$ & $34,425.62$ & $62,241.26$ \\
\hline Total cost (for system) per kilometer & 0.54 & 0.63 & 0.59 \\
\hline \multicolumn{4}{|l|}{ Exhaust System Repairs (ATA VMRS 43) } \\
\hline Parts cost & 0 & 0 & 0 \\
\hline Labor hours & 0 & 0 & 0 \\
\hline Labor cost & 0 & 0 & 0 \\
\hline Total cost (for system) & 0.00 & 0.00 & 0.00 \\
\hline Total cost (for system) per bus & 0.00 & 0.00 & 0.00 \\
\hline Total cost (for system) per kilometer & 0.00 & 0.00 & 0.00 \\
\hline \multicolumn{4}{|l|}{ Fuel System Repairs (ATA VMRS 44) } \\
\hline Parts cost & $13,679.26$ & $19,825.15$ & $33,504.41$ \\
\hline Labor hours & 910.1 & 572.2 & $1,482.3$ \\
\hline Labor cost & $40,204.24$ & $37,379.52$ & $77,583.76$ \\
\hline Total cost (for system) & $53,883.50$ & $57,204.67$ & $111,088.17$ \\
\hline Total cost (for system) per bus & $2,694.18$ & $2,860.23$ & $5,554.41$ \\
\hline Total cost (for system) per kilometer & 0.05 & 0.05 & 0.05 \\
\hline \multicolumn{4}{|c|}{ Power Plant (Engine) Repairs (ATA VMRS 45) } \\
\hline Parts cost & 7179.81 & 12308.842 & $19,488.65$ \\
\hline Labor hours & 3032.86 & 1771.23 & $4,804.1$ \\
\hline Labor cost & $143,167.80$ & $113,409.20$ & $256,577.00$ \\
\hline Total cost (for system) & $150,347.61$ & $125,718.04$ & $276,065.65$ \\
\hline Total cost (for system) per bus & $7,517.38$ & $6,285.90$ & $13,803.28$ \\
\hline Total cost (for system) per kilometer & 0.15 & 0.11 & 0.13 \\
\hline \multicolumn{4}{|c|}{ Electric Propulsion Repairs (ATA VMRS 46) } \\
\hline Parts cost & $8,529.89$ & $18,298.94$ & $26,828.83$ \\
\hline Labor hours & 3348.2 & 2551.43 & $5,899.6$ \\
\hline Labor cost & $108,543.96$ & $165,931.88$ & $274,475.84$ \\
\hline Total cost (for system) & $117,073.85$ & $184,230.82$ & $301,304.67$ \\
\hline Total cost (for system) per bus & $5,853.69$ & $9,211.54$ & $15,065.23$ \\
\hline Total cost (for system) per kilometer & 0.11 & 0.17 & 0.14 \\
\hline
\end{tabular}


Breakdown of Maintenance Costs by Vehicle System (continued)

\begin{tabular}{|c|c|c|c|}
\hline & FCEB Year 1 & FCEB Year 2 & FCEB Total \\
\hline \multicolumn{4}{|c|}{$\begin{array}{l}\text { Electrical System Repairs (ATA VMRS 30-Electrical General, 31-Charging, 32-Cranking, 33- } \\
\text { Ignition) }\end{array}$} \\
\hline Parts cost & $11,323.95$ & $35,172.83$ & $46,496.78$ \\
\hline Labor hours & 1352.22 & 858.04 & $2,210.3$ \\
\hline Labor cost & $35,935.46$ & $60,050.56$ & $95,986.02$ \\
\hline Total cost (for system) & $47,259.41$ & $95,223.39$ & $142,482.80$ \\
\hline Total cost (for system) per bus & $2,362.97$ & $4,761.17$ & $7,124.14$ \\
\hline Total cost (for system) per kilometer & 0.05 & 0.09 & 0.07 \\
\hline \multicolumn{4}{|c|}{ Air Intake System Repairs (ATA VMRS 41) } \\
\hline Parts cost & $29,037.50$ & $11,702.89$ & $40,740.39$ \\
\hline Labor hours & 8.44 & 14.29 & 22.7 \\
\hline Labor cost & 390.95 & 931 & $1,322.0$ \\
\hline Total cost (for system) & $29,428.45$ & $12,633.89$ & $42,062.34$ \\
\hline Total cost (for system) per bus & $1,471.42$ & 631.69 & $2,103.12$ \\
\hline Total cost (for system) per kilometer & 0.03 & 0.01 & 0.02 \\
\hline \multicolumn{4}{|l|}{ Cooling System Repairs (ATA VMRS 42) } \\
\hline Parts cost & 21842.21 & 37382.177 & $59,224.39$ \\
\hline Labor hours & 1306.53 & 1393.17 & $2,699.7$ \\
\hline Labor cost & $59,895.70$ & $90,918.45$ & $150,814.15$ \\
\hline Total cost (for system) & $81,737.91$ & $128,300.63$ & $210,038.54$ \\
\hline Total cost (for system) per bus & $4,086.90$ & $6,415.03$ & $10,501.93$ \\
\hline Total cost (for system) per kilometer & 0.08 & 0.12 & 0.10 \\
\hline \multicolumn{4}{|c|}{ Hydraulic System Repairs (ATA VMRS 65) } \\
\hline Parts cost & 0 & 0 & 0.00 \\
\hline Labor hours & 0 & 0 & 0.0 \\
\hline Labor cost & 0 & 0 & 0.00 \\
\hline Total cost (for system) & 0.00 & 0.00 & 0.00 \\
\hline Total cost (for system) per bus & 0.00 & 0.00 & 0.00 \\
\hline Total cost (for system) per kilometer & 0.00 & 0.00 & 0.00 \\
\hline \multicolumn{4}{|c|}{ General Air System Repairs (ATA VMRS 10) } \\
\hline Parts cost & $2,382.51$ & $18,718.36$ & $21,100.87$ \\
\hline Labor hours & 249.26 & 196.68 & 445.9 \\
\hline Labor cost & $12,688.91$ & $12,998.21$ & $25,687.12$ \\
\hline Total cost (for system) & $15,071.42$ & $31,716.57$ & $46,787.99$ \\
\hline Total cost (for system) per bus & 753.57 & $1,585.83$ & $2,339.40$ \\
\hline Total cost (for system) per kilometer & 0.01 & 0.03 & 0.02 \\
\hline
\end{tabular}


Breakdown of Maintenance Costs by Vehicle System (continued)

\begin{tabular}{|c|c|c|c|}
\hline & FCEB Year 1 & FCEB Year 2 & FCEB Total \\
\hline \multicolumn{4}{|l|}{ Brake System Repairs (ATA VMRS 13) } \\
\hline Parts cost & 4616.92 & 6803.82 & $11,420.74$ \\
\hline Labor hours & 425.84 & 582.84 & $1,008.7$ \\
\hline Labor cost & $24,479.90$ & $37,289.78$ & $61,769.68$ \\
\hline Total cost (for system) & $29,096.82$ & $44,093.60$ & $73,190.42$ \\
\hline Total cost (for system) per bus & $1,454.84$ & $2,204.68$ & $3,659.52$ \\
\hline Total cost (for system) per kilometer & 0.03 & 0.04 & 0.03 \\
\hline \multicolumn{4}{|l|}{ Compressor Repairs } \\
\hline Parts cost & 203.41 & 114.2 & 317.61 \\
\hline Labor hours & 638.64 & 314.55 & 953.2 \\
\hline Labor cost & 24904.85 & 19988.33 & $44,893.18$ \\
\hline Total cost (for system) & $25,108.26$ & $20,102.53$ & $45,210.79$ \\
\hline Total cost (for system) per bus & $1,255.41$ & $1,005.13$ & $2,260.54$ \\
\hline Total cost (for system) per kilometer & 0.02 & 0.02 & 0.02 \\
\hline \multicolumn{4}{|c|}{ Inspections Only - no parts replacements (101) } \\
\hline Parts cost & 0 & 0 & 0.00 \\
\hline Labor hours & 2614.75 & 1713.63 & $4,328.4$ \\
\hline Labor cost & $156,939.12$ & $113,659.32$ & $270,598.44$ \\
\hline Total cost (for system) & $156,939.12$ & $113,659.32$ & $270,598.44$ \\
\hline Total cost (for system) per bus & $7,846.96$ & $5,682.97$ & $13,529.92$ \\
\hline Total cost (for system) per kilometer & 0.15 & 0.10 & 0.13 \\
\hline \multicolumn{4}{|c|}{$\begin{array}{l}\text { Cab, Body, and Accessories Systems Repairs (ATA VMRS 02-Cab and Sheet Metal, 50- } \\
\text { Accessories, 71-Body) }\end{array}$} \\
\hline Parts cost & $25,976.18$ & $46,745.29$ & $72,721.47$ \\
\hline Labor hours & $1,799.84$ & $1,391.06$ & $3,190.9$ \\
\hline Labor cost & $100,719.03$ & $91,164.24$ & $191,883.27$ \\
\hline Total cost (for system) & $126,695.21$ & $137,909.53$ & $264,604.74$ \\
\hline Total cost (for system) per bus & $6,334.76$ & $6,895.48$ & $13,230.24$ \\
\hline Total cost (for system) per kilometer & 0.12 & 0.13 & 0.12 \\
\hline \multicolumn{4}{|l|}{ HVAC System Repairs (ATA VMRS 01) } \\
\hline Parts cost & 14943.56 & 15206.913 & $30,150.47$ \\
\hline Labor hours & 481.72 & 392.82 & 874.5 \\
\hline Labor cost & 25344.98 & 26131.17 & $51,476.15$ \\
\hline Total cost (for system) & $40,288.54$ & $41,338.08$ & $81,626.62$ \\
\hline Total cost (for system) per bus & $2,014.43$ & $2,066.90$ & $4,081.33$ \\
\hline Total cost (for system) per kilometer & 0.04 & 0.04 & 0.04 \\
\hline
\end{tabular}


Breakdown of Maintenance Costs by Vehicle System (continued)

\begin{tabular}{|c|c|c|c|}
\hline & FCEB Year 1 & FCEB Year 2 & FCEB Total \\
\hline \multicolumn{4}{|c|}{ Lighting System Repairs (ATA VMRS 34) } \\
\hline Parts cost & 7692.95 & 3322.302 & $11,015.25$ \\
\hline Labor hours & 241.28 & 163.33 & 404.6 \\
\hline Labor cost & $13,413.74$ & $10,585.95$ & $23,999.69$ \\
\hline Total cost (for system) & $21,106.69$ & $13,908.25$ & $35,014.94$ \\
\hline Total cost (for system) per bus & $1,055.33$ & 695.41 & $1,750.75$ \\
\hline Total cost (for system) per kilometer & 0.02 & 0.01 & 0.02 \\
\hline \multicolumn{4}{|c|}{$\begin{array}{l}\text { Frame, Steering, and Suspension Repairs (ATA VMRS 14-Frame, 15-Steering, 16- } \\
\text { Suspension) }\end{array}$} \\
\hline Parts cost & $9,701.70$ & $23,772.59$ & $33,474.29$ \\
\hline Labor hours & 551.49 & 530.2 & $1,081.7$ \\
\hline Labor cost & $30,462.76$ & $34,660.60$ & $65,123.36$ \\
\hline Total cost (for system) & $40,164.46$ & $58,433.19$ & $98,597.65$ \\
\hline Total cost (for system) per bus & $2,008.22$ & $2,921.66$ & $4,929.88$ \\
\hline Total cost (for system) per kilometer & 0.04 & 0.05 & 0.05 \\
\hline \multicolumn{4}{|c|}{$\begin{array}{l}\text { Axle, Wheel, and Drive Shaft Repairs (ATA VMRS 11-Front Axle, 18-Wheels, 22-Rear Axle, } \\
\text { 24-Drive Shaft) }\end{array}$} \\
\hline Parts cost & 289.25 & 152.54 & 441.79 \\
\hline Labor hours & 33.17 & 30.72 & 63.9 \\
\hline Labor cost & $1,422.56$ & $2,082.57$ & $3,505.13$ \\
\hline Total cost (for system) & $1,711.81$ & $2,235.11$ & $3,946.92$ \\
\hline Total cost (for system) per bus & 85.59 & 111.76 & 197.35 \\
\hline Total cost (for system) per kilometer & 0.00 & 0.00 & 0.00 \\
\hline \multicolumn{4}{|l|}{ Tire Repairs (ATA VMRS 17) } \\
\hline Parts cost & 43.58 & 36.78 & 80.36 \\
\hline Labor hours & 423.81 & 459.87 & 883.7 \\
\hline Labor cost & 25078.66 & 30614.07 & $55,692.73$ \\
\hline Total cost (for system) & $25,122.24$ & $30,650.85$ & $55,773.09$ \\
\hline Total cost (for system) per bus & $1,256.11$ & $1,532.54$ & $2,788.65$ \\
\hline Total cost (for system) per kilometer & 0.02 & 0.03 & 0.03 \\
\hline \multicolumn{4}{|l|}{ Brusa Charges } \\
\hline Parts cost & 0 & 0 & 0.00 \\
\hline Labor hours & 1054.97 & 978.46 & $2,033.4$ \\
\hline Labor cost & 51473.86 & 65098.37 & $116,572.23$ \\
\hline Total cost (for system) & $51,473.86$ & $65,098.37$ & $116,572.23$ \\
\hline Total cost (for system) per bus & $2,573.69$ & $3,254.92$ & $5,828.61$ \\
\hline Total cost (for system) per mile & 0.05 & 0.06 & 0.05 \\
\hline
\end{tabular}




\section{Notes}

1. To compare the hydrogen fuel dispensed and fuel economy to diesel, the hydrogen dispensed was also converted into diesel energy equivalent gallons. Actual energy content will vary by locations, but the general energy conversions are as follows:

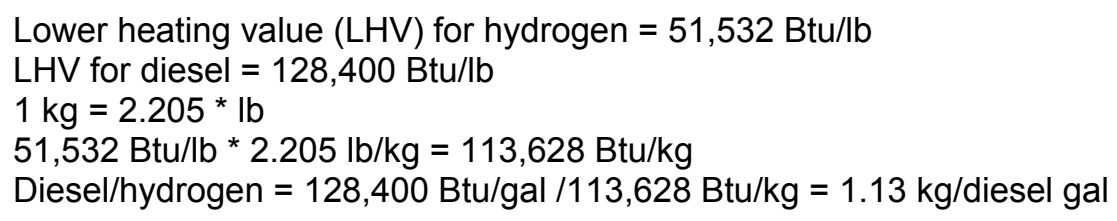

2. The propulsion-related systems were chosen to include only those systems of the vehicles that could be affected directly by the selection of a fuel/advanced technology.

3. ATA VMRS coding is based on parts that were replaced. If there was no part replaced in a given repair, then the code was chosen by the system being worked on.

4. In general, inspections (with no part replacements) were included only in the overall totals (not by system). Category 101 was created to track labor costs for PM inspections.

5. ATA VMRS 02-Cab and Sheet Metal represents seats, doors, etc.; ATA VMRS 50-Accessories represents things like fire extinguishers, test kits, etc.; ATA VMRS 71-Body represents mostly windows and windshields.

6. Average labor cost is assumed to be $\$ 50$ per hour.

7. Warranty costs are not included. 


\section{Appendix B: Fleet Summary Statistics-U.S. Units Fleet Summary Statistics: BC Transit FCEB Fleet Operations and Economics}

\begin{tabular}{|l|r|r|r|}
\hline & FCEB Year 1 & FCEB Year 2 & FCEB Total \\
\hline Number of vehicles & 20 & 20 & 20 \\
\hline Period used for fuel and oil op analysis & $4 / 11-3 / 12$ & $4 / 12-3 / 13$ & $4 / 11-3 / 13$ \\
\hline Total number of months in period & 12 & 12 & 24 \\
\hline Fuel and oil analysis base fleet miles & 597,916 & 682,038 & $1,279,954$ \\
\hline Period used for maintenance op analysis & $4 / 11-3 / 12$ & $4 / 12-3 / 13$ & $4 / 11-3 / 13$ \\
\hline Total number of months in period & 12 & 12 & 24 \\
\hline Maintenance analysis base fleet miles & 636,313 & 682,517 & $1,318,830$ \\
\hline Average monthly miles per vehicle & 2,651 & 2,844 & 2,748 \\
\hline Availability & $69 \%$ & $69 \%$ & $69 \%$ \\
\hline Fleet fuel usage (H in $_{2}$ kg/ diesel in & 148,707 & 170,237 & 318,944 \\
gallons) & 412 & 454 & 866 \\
\hline Roadcalls & 1,544 & 1,503 & 1,523 \\
\hline RCs MBRC & 308 & 347 & 655 \\
\hline Propulsion roadcalls & 2,066 & 1,967 & 2,013 \\
\hline Propulsion MBRC & 4.02 & 4.01 & 4.01 \\
\hline Fleet mi/kg hydrogen (1.13 kg H2) & 4.54 & 4.53 & 4.53 \\
\hline Rep. fleet fuel consumption (mi/DGE) & 10.55 & 10.55 & 10.55 \\
\hline Hydrogen cost per kg & $\mathbf{2 . 6 2}$ & $\mathbf{2 . 6 3}$ & $\mathbf{2 . 6 3}$ \\
\hline Fuel cost per mile & 0.37 & 0.27 & 0.32 \\
\hline Total scheduled repair cost per mile & 1.17 & 1.37 & 1.27 \\
\hline Total unscheduled repair cost per mile & $\mathbf{1 . 5 4}$ & $\mathbf{1 . 6 5}$ & $\mathbf{1 . 6 0}$ \\
\hline Total maintenance cost per mile & $\mathbf{4 . 1 7}$ & $\mathbf{4 . 2 8}$ & $\mathbf{4 . 2 3}$ \\
\hline Total operating cost per mile & & & \\
\hline
\end{tabular}

\section{Maintenance Costs}

\begin{tabular}{|l|r|r|r|}
\hline & FCEB Year 1 & FCEB Year 2 & FCEB Total \\
\hline Fleet mileage & 636,313 & 682,517 & $1,318,830$ \\
\hline Total parts cost & $152,247.07$ & $241,328.02$ & $393,575.10$ \\
\hline Total labor hours & $18,473.12$ & $13,914.48$ & $32,387.60$ \\
\hline Labor cost & $826,849.29$ & $882,767.74$ & $1,709,617.03$ \\
\hline Total maintenance cost & $979,096.36$ & $1,124,095.77$ & $2,103,192.13$ \\
\hline Total maintenance cost per bus & $48,954.82$ & $56,204.79$ & $105,159.61$ \\
\hline Total maintenance cost per mile & $\mathbf{1 . 5 4}$ & $\mathbf{1 . 6 5}$ & $\mathbf{1 . 5 9}$ \\
\hline
\end{tabular}




\section{Breakdown of Maintenance Costs by Vehicle System}

\begin{tabular}{|c|c|c|c|}
\hline & FCEB Year 1 & FCEB Year 2 & FCEB Total \\
\hline Fleet mileage & 636,313 & 682,517 & $1,318,830$ \\
\hline \multicolumn{4}{|c|}{ Total Engine/Fuel-Related Systems (ATA VMRS 27, 30, 31, 32, 33, 41, 42, 43, 44, 45, 46, 65) } \\
\hline Parts cost & $88,766.76$ & $130,356.47$ & $219,123.23$ \\
\hline Labor hours & $11,651.96$ & $8,453.33$ & $20,105.29$ \\
\hline Labor cost & $449,187.76$ & $535,434.97$ & $984,622.73$ \\
\hline Total cost (for system) & $537,954.53$ & $665,791.44$ & $1,203,745.96$ \\
\hline Total cost (for system) per bus & $26,897.73$ & $33,289.57$ & $60,187.30$ \\
\hline Total cost (for system) per mile & 0.85 & 0.98 & 0.91 \\
\hline \multicolumn{4}{|c|}{ Exhaust System Repairs (ATA VMRS 43) } \\
\hline Parts cost & 0.00 & 0.00 & 0.00 \\
\hline Labor hours & 0.00 & 0.00 & 0.00 \\
\hline Labor cost & 0.00 & 0.00 & 0.00 \\
\hline Total cost (for system) & 0.00 & 0.00 & 0.00 \\
\hline Total cost (for system) per bus & 0.00 & 0.00 & 0.00 \\
\hline Total cost (for system) per mile & 0.00 & 0.00 & 0.00 \\
\hline \multicolumn{4}{|c|}{ Fuel System Repairs (ATA VMRS 44) } \\
\hline Parts cost & $13,227.84$ & $19,170.92$ & $32,398.77$ \\
\hline Labor hours & 910.1 & 572.2 & $1,482.3$ \\
\hline Labor cost & $38,877.50$ & $36,146.00$ & $75,023.50$ \\
\hline Total cost (for system) & $52,105.34$ & $55,316.92$ & $107,422.26$ \\
\hline Total cost (for system) per bus & $2,605.27$ & $2,765.85$ & $5,371.11$ \\
\hline Total cost (for system) per mile & 0.08 & 0.08 & 0.08 \\
\hline \multicolumn{4}{|c|}{ Power Plant (Engine) Repairs (ATA VMRS 45) } \\
\hline Parts cost & $6,942.88$ & $11,902.65$ & $18,845.53$ \\
\hline Labor hours & $3,032.9$ & $1,771.2$ & $4,804.1$ \\
\hline Labor cost & $138,443.26$ & $109,666.70$ & $248,109.96$ \\
\hline Total cost (for system) & $145,386.14$ & $121,569.35$ & $266,955.49$ \\
\hline Total cost (for system) per bus & $7,269.31$ & $6,078.47$ & $13,347.77$ \\
\hline Total cost (for system) per mile & 0.23 & 0.18 & 0.20 \\
\hline \multicolumn{4}{|c|}{ Electric Propulsion Repairs (ATA VMRS 46) } \\
\hline Parts cost & $8,248.40$ & $17,695.08$ & $25,943.48$ \\
\hline Labor hours & $3,348.2$ & $2,551.4$ & $5,899.6$ \\
\hline Labor cost & $104,962.01$ & $160,456.13$ & $265,418.14$ \\
\hline Total cost (for system) & $113,210.41$ & $178,151.21$ & $291,361.62$ \\
\hline Total cost (for system) per bus & $5,660.52$ & $8,907.56$ & $14,568.08$ \\
\hline Total cost (for system) per mile & 0.18 & 0.26 & 0.22 \\
\hline
\end{tabular}


Breakdown of Maintenance Costs by Vehicle System (continued)

\begin{tabular}{|c|c|c|c|}
\hline & FCEB Year 1 & FCEB Year 2 & FCEB Total \\
\hline \multicolumn{4}{|c|}{$\begin{array}{l}\text { Electrical System Repairs (ATA VMRS 30-Electrical General, 31-Charging, 32-Cranking, 33- } \\
\text { Ignition) }\end{array}$} \\
\hline Parts cost & $10,950.26$ & $34,012.13$ & $44,962.39$ \\
\hline Labor hours & $1,352.2$ & 858.0 & $2,210.3$ \\
\hline Labor cost & $34,749.59$ & $58,068.89$ & $92,818.48$ \\
\hline Total cost (for system) & $45,699.85$ & $92,081.02$ & $137,780.87$ \\
\hline Total cost (for system) per bus & $2,284.99$ & $4,604.05$ & $6,889.04$ \\
\hline Total cost (for system) per mile & 0.07 & 0.13 & 0.10 \\
\hline \multicolumn{4}{|c|}{ Air Intake System Repairs (ATA VMRS 41) } \\
\hline Parts cost & $28,079.26$ & $11,316.69$ & $39,395.96$ \\
\hline Labor hours & 8.4 & 14.3 & 22.7 \\
\hline Labor cost & 378.05 & 900.28 & $1,278.33$ \\
\hline Total cost (for system) & $28,457.31$ & $12,216.97$ & $40,674.28$ \\
\hline Total cost (for system) per bus & $1,422.87$ & 610.85 & $2,033.71$ \\
\hline Total cost (for system) per mile & 0.04 & 0.02 & 0.03 \\
\hline \multicolumn{4}{|c|}{ Cooling System Repairs (ATA VMRS 42) } \\
\hline Parts cost & $21,121.42$ & $36,148.57$ & $57,269.98$ \\
\hline Labor hours & $1,306.5$ & $1,393.2$ & $2,699.7$ \\
\hline Labor cost & $57,919.14$ & $87,918.14$ & $145,837.28$ \\
\hline Total cost (for system) & $79,040.56$ & $124,066.71$ & $203,107.27$ \\
\hline Total cost (for system) per bus & $3,952.03$ & $6,203.34$ & $10,155.36$ \\
\hline Total cost (for system) per mile & 0.12 & 0.18 & 0.15 \\
\hline \multicolumn{4}{|c|}{ Hydraulic System Repairs (ATA VMRS 65) } \\
\hline Parts cost & 0.00 & 0.00 & 0.00 \\
\hline Labor hours & 0.0 & 0.0 & 0.0 \\
\hline Labor cost & 0.00 & 0.00 & 0.00 \\
\hline Total cost (for system) & 0.00 & 0.00 & 0.00 \\
\hline Total cost (for system) per bus & 0.00 & 0.00 & 0.00 \\
\hline Total cost (for system) per mile & 0.00 & 0.00 & 0.00 \\
\hline \multicolumn{4}{|c|}{ General Air System Repairs (ATA VMRS 10) } \\
\hline Parts cost & $2,303.89$ & $18,100.65$ & $20,404.54$ \\
\hline Labor hours & 249.3 & 196.7 & 445.9 \\
\hline Labor cost & $12,270.18$ & $12,569.27$ & $24,839.45$ \\
\hline Total cost (for system) & $14,574.06$ & $30,669.92$ & $45,243.98$ \\
\hline Total cost (for system) per bus & 728.70 & $1,533.50$ & $2,262.20$ \\
\hline Total cost (for system) per mile & 0.02 & 0.04 & 0.03 \\
\hline
\end{tabular}


Breakdown of Maintenance Costs by Vehicle System (continued)

\begin{tabular}{|c|c|c|c|}
\hline & FCEB Year 1 & FCEB Year 2 & FCEB Total \\
\hline \multicolumn{4}{|c|}{ Brake System Repairs (ATA VMRS 13) } \\
\hline Parts cost & $4,464.56$ & $6,579.29$ & $11,043.86$ \\
\hline Labor hours & 425.8 & 582.8 & $1,008.7$ \\
\hline Labor cost & $23,672.06$ & $36,059.22$ & $59,731.28$ \\
\hline Total cost (for system) & $28,136.62$ & $42,638.51$ & $70,775.14$ \\
\hline Total cost (for system) per bus & $1,406.83$ & $2,131.93$ & $3,538.76$ \\
\hline Total cost (for system) per mile & 0.04 & 0.06 & 0.05 \\
\hline \multicolumn{4}{|l|}{ Compressor Repairs } \\
\hline Parts cost & 196.70 & 110.43 & 307.13 \\
\hline Labor hours & 638.6 & 314.6 & 953.2 \\
\hline Labor cost & $24,082.99$ & $19,328.72$ & $43,411.71$ \\
\hline Total cost (for system) & $24,279.69$ & $19,439.15$ & $43,718.83$ \\
\hline Total cost (for system) per bus & $1,213.98$ & 971.96 & $2,185.94$ \\
\hline Total cost (for system) per mile & 0.04 & 0.03 & 0.03 \\
\hline \multicolumn{4}{|c|}{ Inspections Only - no parts replacements (101) } \\
\hline Parts cost & 0.00 & 0.00 & 0.00 \\
\hline Labor hours & $2,614.8$ & $1,713.6$ & $4,328.4$ \\
\hline Labor cost & $151,760.13$ & $109,908.56$ & $261,668.69$ \\
\hline Total cost (for system) & $151,760.13$ & $109,908.56$ & $261,668.69$ \\
\hline Total cost (for system) per bus & $7,588.01$ & $5,495.43$ & $13,083.43$ \\
\hline Total cost (for system) per mile & 0.24 & 0.16 & 0.20 \\
\hline \multicolumn{4}{|c|}{$\begin{array}{l}\text { Cab, Body, and Accessories Systems Repairs (ATA VMRS 02-Cab and Sheet Metal, 50-Accessories, } \\
\text { 71-Body) }\end{array}$} \\
\hline Parts cost & $25,118.97$ & $45,202.70$ & $70,321.66$ \\
\hline Labor hours & $1,799.8$ & $1,391.1$ & $3,190.9$ \\
\hline Labor cost & $97,395.30$ & $88,155.82$ & $185,551.12$ \\
\hline Total cost (for system) & $122,514.27$ & $133,358.52$ & $255,872.79$ \\
\hline Total cost (for system) per bus & $6,125.71$ & $6,667.93$ & $12,793.64$ \\
\hline Total cost (for system) per mile & 0.19 & 0.20 & 0.19 \\
\hline \multicolumn{4}{|c|}{ HVAC System Repairs (ATA VMRS 01) } \\
\hline Parts cost & $14,450.42$ & $14,705.08$ & $29,155.51$ \\
\hline Labor hours & 481.7 & 392.8 & 874.5 \\
\hline Labor cost & $24,508.60$ & $25,268.84$ & $49,777.44$ \\
\hline Total cost (for system) & $38,959.02$ & $39,973.93$ & $78,932.94$ \\
\hline Total cost (for system) per bus & $1,947.95$ & $1,998.70$ & $3,946.65$ \\
\hline Total cost (for system) per mile & 0.06 & 0.06 & 0.06 \\
\hline
\end{tabular}


Breakdown of Maintenance Costs by Vehicle System (continued)

\begin{tabular}{|c|c|c|c|}
\hline & FCEB Year 1 & FCEB Year 2 & FCEB Total \\
\hline \multicolumn{4}{|c|}{ Lighting System Repairs (ATA VMRS 34) } \\
\hline Parts cost & $7,439.08$ & $3,212.67$ & $10,651.75$ \\
\hline Labor hours & 241.3 & 163.3 & 404.6 \\
\hline Labor cost & $12,971.09$ & $10,236.61$ & $23,207.70$ \\
\hline Total cost (for system) & $20,410.17$ & $13,449.28$ & $33,859.45$ \\
\hline Total cost (for system) per bus & $1,020.51$ & 672.46 & $1,692.97$ \\
\hline Total cost (for system) per mile & 0.03 & 0.02 & 0.03 \\
\hline \multicolumn{4}{|c|}{$\begin{array}{l}\text { Frame, Steering, and Suspension Repairs (ATA VMRS 14-Frame, 15-Steering, 16- } \\
\text { Suspension) }\end{array}$} \\
\hline Parts cost & $9,381.54$ & $22,988.09$ & $32,369.63$ \\
\hline Labor hours & 551.5 & 530.2 & $1,081.7$ \\
\hline Labor cost & $29,457.49$ & $33,516.80$ & $62,974.29$ \\
\hline Total cost (for system) & $38,839.03$ & $56,504.89$ & $95,343.92$ \\
\hline Total cost (for system) per bus & $1,941.95$ & $2,825.24$ & $4,767.20$ \\
\hline Total cost (for system) per mile & 0.06 & 0.08 & 0.07 \\
\hline \multicolumn{4}{|c|}{$\begin{array}{l}\text { Axle, Wheel, and Drive Shaft Repairs (ATA VMRS 11-Front Axle, 18-Wheels, 22-Rear Axle, } \\
\text { 24-Drive Shaft) }\end{array}$} \\
\hline Parts cost & 279.70 & 147.51 & 427.21 \\
\hline Labor hours & 33.2 & 30.7 & 63.9 \\
\hline Labor cost & $1,375.62$ & $2,013.85$ & $3,389.46$ \\
\hline Total cost (for system) & $1,655.32$ & $2,161.35$ & $3,816.67$ \\
\hline Total cost (for system) per bus & 82.77 & 108.07 & 190.83 \\
\hline Total cost (for system) per mile & 0.00 & 0.00 & 0.00 \\
\hline \multicolumn{4}{|l|}{ Tire Repairs (ATA VMRS 17) } \\
\hline Parts cost & 42.14 & 35.57 & 77.71 \\
\hline Labor hours & 423.8 & 459.9 & 883.7 \\
\hline Labor cost & $24,251.06$ & $29,603.81$ & $53,854.87$ \\
\hline Total cost (for system) & $24,293.21$ & $29,639.37$ & $53,932.58$ \\
\hline Total cost (for system) per bus & $1,214.66$ & $1,481.97$ & $2,696.63$ \\
\hline Total cost (for system) per mile & 0.04 & 0.04 & 0.04 \\
\hline \multicolumn{4}{|l|}{ Brusa Charges } \\
\hline Parts cost & 0.00 & 0.00 & 0.00 \\
\hline Labor hours & $1,055.0$ & 978.5 & $2,033.4$ \\
\hline Labor cost & $49,775.22$ & $62,950.12$ & $112,725.35$ \\
\hline Total cost (for system) & $49,775.22$ & $62,950.12$ & $112,725.35$ \\
\hline Total cost (for system) per bus & $2,488.76$ & $3,147.51$ & $5,636.27$ \\
\hline Total cost (for system) per mile & 0.08 & 0.09 & 0.09 \\
\hline
\end{tabular}

